\title{
Diet quality - what is it and does it matter?
}

\author{
Annika Wirt and Clare E Collins* \\ School of Health Sciences, HA12 Hunter Building, University Drive, University of Newcastle, Callaghan, \\ New South Wales 2308, Australia
}

Submitted 18 May 2008: Accepted 5 February 2009: First published online 1 April 2009

\begin{abstract}
Objective: Measures of diet quality have evolved with a number of scoring indices currently in use. They are increasingly being used to examine epidemiological associations between dietary intake and nutrition-related health outcomes. The present review aims to describe current diet quality tools and their applications, and to examine the relationship between diet quality and morbidity and mortality. Design: A search was conducted of MEDLINE, Cochrane, EMBASE, CINAHL and ProQuest electronic databases. Inclusion criteria were: English language; published from 2004 on; conducted in adult populations; longitudinal/cohort/ case-control or cross-sectional study; included a theoretically defined measure of diet quality.

Results: A total of twenty-five indices of overall diet quality and/or variety were found, with components ranging from nutrients only to adherence to recommended food group servings, to variety within healthful food groups. The majority of studies reviewed had methodological weaknesses but demonstrated that higher dietary quality was consistently inversely related to all-cause mortality, with a protective effect of moderate magnitude. The associations were stronger for men and for all-cause and CVD mortality.

Conclusions: The limitations of both the indices and the studies that use them need to be considered when interpreting and comparing results. However, diet quality indices do appear to be able to quantify risk of some health outcomes, including biomarkers of disease and risk of CVD, some cancers and mortality. Further research is needed to improve the validity of these tools and to adapt them for use in clinical dietetic practice.
\end{abstract}

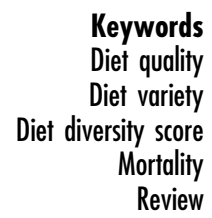

Keywords

Diet quality

Diet variety

Mortality

Review
In recent years, methods for measuring diet quality have evolved and a number of scoring systems or indices to this effect have emerged. This relatively new concept involves the assessment of both quality and variety of the entire diet, enabling examination of associations between whole foods and health status, rather than just nutrients. Diet quality is measured by scoring food patterns in terms of how closely they align with national dietary guidelines and how diverse the variety of healthy choices is within core food groups or equivalent international groupings. More refined scoring methods allow both protective dietary patterns and unfavourable intakes to be identified. As diet quality and variety scores have been examined in association with health outcomes cross-sectionally and to predict such outcomes longitudinally, nutrition interventions could potentially be developed to target improvements in the most critical aspects of an individual's or population's food intake; for example, targeting an increase in fruit and vegetable consumption if an index shows a strong relationship between low intake and CVD.

Kant has previously published two reviews of diet quality indices ${ }^{(1,2)}$, indicating a need for additional validation studies to assess the effectiveness of these indices in predicting nutritional and health status. Thus the aims of the present review were to:

1. Describe current diet quality tools and their applications.

2. Analyse whether higher diet quality scores are associated with lower levels of morbidity and mortality.

3. Examine how robust the studies of association between diet quality and morbidity and mortality are in relation to their findings.

\section{Methods}

\section{Search strategy for identification of studies}

A systematic review of published English-language literature from 2004 to 2007 was conducted. Relevant literature prior to this time was identified from the reviews previously published by $\mathrm{Kant}^{(1,2)}$.

The following electronic databases were searched: MEDLINE, Cochrane, EMBASE (Excerpta Medica Database), CINAHL (Cumulative Index to Nursing and Allied Health Literature) and ProQuest. Scopus was used to 
identify studies that had cited Kant's 2004 review $^{(2)}$. The MeSH (Medical Subject Headings of the National Library of Medicine) keyword search terms included diet, dietary, quality, variety, diversity, pattern, score, indicator, index, guideline, Healthy Eating Index, Alternative Healthy Eating Index, Recommended Food Score, chronic disease, cancer, cardiovascular disease; and variations of these.

\section{Selection of studies}

The current review used specific selection criteria for retrieval of studies. Inclusion criteria were: (i) studies of a longitudinal/cohort, case-control or cross-sectional nature; (ii) human subjects; (iii) adults; (iv) English language; (v) literature published from 2004 onwards; and (vi) use of theoretically defined dietary patterns (food indices/scores) or a measure of diet quality created a priori and based on current nutrition knowledge ${ }^{(3)}$. Pertinent literature published in one of Kant's previous reviews ${ }^{(2)}$ was adapted and cited to facilitate the aim of the current review.

Specific exclusion criteria included: (i) studies of nonEnglish language; (ii) studies conducted with children or pregnant women; (iii) intervention studies; (iv) published prior to 2004 , with the exception of $\mathrm{Kant}^{(1,2)}$; (v) studies on animals; and (vi) studies that primarily use dietary patterns derived a posteriori from food consumption data, based and defined empirically or statistically, such as with cluster analysis and factor analysis ${ }^{(3)}$.

Articles were retrieved from the electronic search if information contained in the title, descriptor/MeSH headings and abstract appeared to be consistent with the inclusion criteria. The methodological quality of the articles was critically appraised and a summary was tabulated based on JBI (Joanna Briggs Institute) observational critical appraisal criteria of a random sample, clear inclusion criteria, objective assessment of outcomes, sufficient description of group comparison and appropriate statistical analyses; while study details, key findings and risk reduction ratios were extracted $^{(4,5)}$ and tabulated.

\section{Results}

After retrieval of articles, nine articles were selected. These studies were combined with nineteen studies, previously reviewed by Kant ${ }^{(1,2)}$, giving a total of twentyeight studies included. Table 1 describes the diet quality indices or tools used. Table 2 summarises the quality assessment. Tables 3 and 4 summarise the main features of studies validating the indices cross-sectionally or in a case-control design with biomarker or health outcomes, including the dietary assessment measure, population, main results and study limitations.

\section{Diet quality indices and scores}

A total of twenty-five indices of overall diet quality and/or variety were identified (Table 1). The major indices include the Healthy Eating Index (HEI) ${ }^{(6)}$, the Healthy Diet Indicator $(\mathrm{HDI})^{(7)}$, the Healthy Food Index $(\mathrm{HFI})^{(8)}$, the Recommended Food Score (RFS) ${ }^{(9)}$, the Diet Quality Index (DQI) ${ }^{(10)}$, the Diet Quality Score (DQS) ${ }^{(11)}$ and the Mediterranean Diet Score (MDS) ${ }^{(12)}$. Table 1 describes each index, the variations or modifications derived from them and validation studies ${ }^{(6,13-15)}$. The Diet Quality Index International (DQI-I) ${ }^{(16)}$ was not included because rather than examine associations with disease outcomes it compared diet quality between countries.

The majority of indices are based on national nutrition recommendations and national dietary guidelines specific to the country where the tool was developed. Adherence to these recommendations is assessed by the diet quality/ variety score and then commonly compared with nutrient intakes (not reported here) and the risk for various health outcomes, including biomarkers of disease, mortality and chronic diseases such as CVD and cancer (Table 2). While most indices have been created for use with the US population, indices based on the Mediterranean diet have emerged due to recent research highlighting associations with reduced risk of CVD and some types of cancer $^{(3,12,17-20)}$.

Kant highlighted in $1996^{(1)}$ that the construction of diet quality indices has taken three major approaches: (i) based on food groups or specific foods; (ii) based on nutrient intakes; or (iii) derived from combinations of foods and nutrient intakes. In 2007 Waijers et al. added that current scores were based on adherence to established national dietary guidelines or a Mediterranean pattern ${ }^{(3)}$. Depending on inclusion or exclusion of specific foods and/or nutrients, diet quality indices can be generated to reflect a dietary intake that is healthy, unhealthy or a combination of both ${ }^{(3)}$. Most indices, including the HEI and DQI, are based on both food groups and nutrients, while some, such as the HFI, are based on foods and food groups (Table 1). The food items and groups selected as components of the indices include vegetables, fruits, cereals and grains, meat products and dairy products, with some specifically including fish and olive oil ${ }^{(3)}$. Common nutrient components used in scores include total fat, ratios of fat types (ratio of saturated fat to mono- or polyunsaturated fat) and cholesterol ${ }^{(3)}$. Alcohol is used in some indices ${ }^{(12,17-22)}$, predominantly Mediterranean indices, in recognition of the proposed beneficial effects and to evaluate associations with health outcomes ${ }^{(3)}$. Other nutrients used include $\mathrm{Na}$, dietary fibre, protein and complex carbohydrates ${ }^{(3)}$.

Dietary variety or diversity is included in some indices (HEI, HEI-f, DQI-R, total and specific food group diversity and its variations), in addition to foods and nutrients, with higher scores awarded for a more varied diet ${ }^{(3)}$. It has been proposed that variety within food groups may be considered a better indicator of more healthful outcomes ${ }^{(6,13,21,23-27)}$; however, this is not considered important by some authors ${ }^{(3)}$. 
Table 1 Description of diet quality indices

Healthy Eating Single, summary measure of diet quality based Index (HEI) tity based to US Food Guide Pyramid and Dietary Guidelines for Americans

Alternative Healthy Assesses whether AHEI predicts disease risk Eating Index (AHEl) better than $\mathrm{HEI}$. In contrast to $\mathrm{HEI}$ it acknowledges benefits of unsaturated oils, distinguishes quality within food groups, and excludes potato and its products from vegetable group

Healthy Eating Index from Food Frequency Score (HEl-f)

Healthy Diet Indicator (HDI)

Based on WHO dietary recommendations for preventing chronic disease

Healthy Food Index Based on previous diet quality indices and (HFI) current recommendations for a healthy diet ${ }^{(1)}$. Assesses food intake patterns defined a prior on basis of food recommendations and a posterori by factor analysis, using mortality as

Healthy Food and Nutrient Index (HFNI)

Assesses whether high HEl score, calculated from validated FFQ and Healthy Eating Index Final Report guidelines, predicts lower
Ten components based on aspects of a healthy diet: each contributes 0-10 points. Score range: 0 (worst)-100 (best). Components 1-5 based on conforming to serving recommendations of the US Food Guide Pyramid for five major groups including grains; vegetables; fruit; meat; milk. Others based on overall fat \% energy; saturated fat \% energy; cholesterol; $\mathrm{Na}$; variety in diet

Nine components including vegetables; fruit; nuts and soya; ratio of white to red meat; cereal fibre; trans fat \% energy ratio of polyunsaturated fat to saturated fat; alcoho

servings daily; duration of multivitamin use. Eight of nine components contribute $0-10$ points each, with 10 indicating recommendations met and 0 indicating the least healthy dietary behaviour. Intermediate intakes scored

proportionally between 0 and 10 . Component scores summed for AHEI total ranging from 2.5 (worst) to 87.5 (best)

Similar to original HEI. Ten components based on aspects of a healthy diet: each contributes $0-10$ points. Score range: 0 (worst)-100 (best). Components 1-5 based on conforming to serving recommendations of US Food Guide Pyramid for five major groups including grains; vegetables; fruit; meat; milk. Others based on overall fat \% energy; saturated fat $\%$ milk. Others based on overall fat \% energy; saturated fat $\%$
energy; cholesterol; Na; variety in diet. Variety component energy; cholesterol; Na; variety in diet. Variety component
varies from original HEl, changing calculation method from varies from original $\mathrm{HEI}$, changing calculation method from number of unique foods consumed in $3 \mathrm{~d}$ to numb

Dichotomous variables used with 1 indicating being within recommendations and 0 being outside recommendations. $\mathrm{HDI}=$ sum of variables with range from 0 to 9 ( 9 as highest value). Food groups include saturated fat; polyunaturate fat; protein; complex carbohydrates; dietary fibre; legumes nuts/seeds; fruit/vegetable; mono- and disaccharides; cholesterol

Four components, each receiving 1 point if met daily: not consuming margarine, butter or lard; consumption of boiled or raw vegetables at least once; consumption of coarse rye or white bread at least once; consumption of fruit at least once. Score range $0-4$. Score of 4 indicates better diet quality

Eight components based on dietary guidelines. Components include saturated fat; monounsaturated fat;

polyunsaturated fat; protein; dietary fibre; fruit/vegetables carbohydrates; dietary cholesterol. 1 point awarded if consumption is within recommendation limits and 0 is awarded if consumption exceeds limit. Score range $0-8$, with higher score indicating adherence to

recommendations. HFNI expressed in quartiles with 1 being best quartile
$24 \mathrm{~h}$ recall and $2 \mathrm{~d} \quad$ Hann et al. (2001) ${ }^{(6)}$.

food record

Weinstein et al. (2004) ${ }^{(13)}$ Fung et al. (2006) ${ }^{(21)}$

FFQ $(\sim 130$ item $)$

McCullough et al. (2002)(22); Fung et al. (2006)

McCullough et al. (2000)(23). McCullough et al. (2000) ${ }^{(24)}$

Huijbregts et al. (1997) $)^{(7)}$. Huijbregts et al. (1998) Knoops et al. $(2006)^{(20)}$

Osler et al. (2001) ${ }^{(8)}$; Osler et al. $2002^{\left(3^{\circ}\right)}$

Bazelmans et al. (2006) ${ }^{(31)}$ 


\section{Recommended \\ Based on consumption of recommended foods} Food Score (RFS) in current US dietary guidance

Recommended Based on 'good' foods (consumption of foods
from the FFQ list consistent with national dietary guidelines)

Not Recommended Based on 'bad' foods (consumption of foods no Food Score (NRFS)

Diet Quality Index (DQI) (1)

Diet Quality Index Revised (DQI-R)

Improved DQI to reflect current dietary guidelines, incorporate dietary moderation and variety, and improve methods of estimating food servings

Diet Quality Index (DQI) (2)

Diet Quality Score (DQS) (1)

Diet Quality Score (DQS) (2)
Sum of food items (maximum 23) consumed within a week. Dichotomous variables each scoring 1 (for meeting recommendation) or 0 (not meeting the recommendation), with score range of $0-23$ (23 highest score)

Foods consumed 1-3 times monthly score 1 point (maximum of 17). Score range $0-17$, with 17 being best score. Differs slightly from previous RFS with poultry, potato and juices excluded

Foods consumed 1-3 times monthly score 1 point (maximum of 21). Score range $0-21$, with 21 being best score. Some foods included: meat; chips; butter; white bread; cheese. Poultry, potato and juices were excluded

Based on eight National Research Council Diet and Health recommendations. Includes six nutrient intakes: total fat saturated fat; cholesterol; protein; $\mathrm{Ca}$; $\mathrm{Na}$; servings from two food groups: vegetables and fruit, grains. Each component scores 0 (meets recommendation), 1 (recommendation almost met) or 2 (recommendation not met). Score range is $0-16,0$ indicates excellent diet

Ten components instead of eight: each scoring $0-10$ points. Score range: $0-100$. In contrast to DQI, higher scores indicate adherence to dietary guidance. Since modification, fruit and vegetables are separated according to Pyramid recommendations; includes Fe intake; excludes protein intake; and scores dietary moderation and diversity

Similar to previous DQI but modified for Mediterranean population. Now only seven components: saturated fat; cholesterol; olive oil; fish; meat; cereals; vegetables; fruit. Each component scores 0 (meets recommendation), 1 (recommendation almost met) or 2 (recommendation no met). Score range is $0-14$; a score of 0 indicates an excellent diet

Seventeen nutrient categories based on age- and genderspecific recommendations. 1 point awarded for recommendation being met and 0 if not met. Score range is 0-17, with 17 indicating highest compliance. Dietary supplements were excluded

Three-point score developed for four food groups: fish; vegetables; fruit; fats. Recommended intakes of all groups except fats used to calculate upper cut-off points. Fats group used no use of spread or fat for cooking as a cut-of point for its high score. Lower cut-off points defined by using saturated fats; no consumption of fish; or low intake of vegetables and fruit. Participants categorised into three groups for each food group: very unhealthy (1 point), average intake (2 points) and very healthy (3 points). Points totalled for range of $1-12,12$ being most healthy
FFQ

\section{Kant et al. (2000) ${ }^{(9)}$}

McCullough et al. (2002) ${ }^{(22)}$ Mai et al. $(2005)^{(32)}$

Michels and Wolk (2002)(33) Fung et al. (2006) $)^{(21)}$

Michels and Wolk (2002) ${ }^{(33)}$

$24 \mathrm{~h}$ recall and $2 \mathrm{~d}$

Seymour et al. $(2003)^{(10)}$ food record

$24 \mathrm{~h}$ recall

Fung et al. (2006) $)^{(21)}$

FFQ (162 items)

Gerber et al. (2000) ${ }^{(14)}$

FFQ (48-item validated by a 198-item)
Fitzgerald et al. (2002) $)^{(11)}$

Toft et al. (2007) ${ }^{(15)}$ (minimum $600 \mathrm{~g}$ vegetables/fruit each day, minimum $200 \mathrm{~g}$ fish per week and low intake (total fat $<30 \%$ energy intake, 


\begin{tabular}{|c|c|c|c|c|}
\hline Index & Objective & Index method & Dietary method & Study and reference \\
\hline Dietary Quality (DQ) & $\begin{array}{l}\text { Assesses diet quality (2/3 of } 1989 \\
\text { Recommended Dietary Allowance) and its } \\
\text { association with survival. Nutrient-based }\end{array}$ & $\begin{array}{l}\text { Based on number of nutrient intakes that fall below } 67 \% \text { of the } \\
1989 \text { RDA. Eight nutrients analysed: Fe; protein; Ca; vitamin } \\
\text { A; vitamin C; thiamine; riboflavin; preformed niacin. When five } \\
\text { or more nutrients were below } 2 / 3 \text { of RDA diet was classed as } \\
\text { poor quality. Energy intake, food servings per day and } \\
\text { supplement use (not quantified) were also measured }\end{array}$ & $24 \mathrm{~h}$ recall & Murphy et al. (1996) $)^{(34)}$ \\
\hline $\begin{array}{l}\text { Dietary Guidelines } \\
\text { Index (DGI) }\end{array}$ & $\begin{array}{l}\text { Measures compliance with 5th edition of Dietary } \\
\text { Guidelines for Americans. Food-based; } \\
\text { nutrient guidelines excluded. Allows } \\
\text { individuals to be ranked according to } \\
\text { compliance }\end{array}$ & $\begin{array}{l}\text { Each guideline contributes equally to DGI. Made of nine } \\
\text { components each with maximum of } 2 \text { points. Score range } \\
0-18 \text { with } 18 \text { indicating full compliance with guidelines and } \\
0 \text { being non-compliant. Includes diet-related and non diet- } \\
\text { related recommendations }\end{array}$ & FFQ (127 items) & Harnack et al. (2002) \\
\hline
\end{tabular}

Mediterranean Diet Assesses overall diet pattern and survival based Score (MDS) (1) on traditional Mediterranean diet

Mediterranean Diet Assesses overall diet pattern based on Score (MDS) (2) traditional Mediterranean diet

\section{Mediterranean Diet Assesses association between a Mediterranean Score (MDS) (3) diet score and survival in an elderly Danish population; and diet score and biochemical}

Mediterranean Die Score (MDS) (4)

Mediterranean Adequacy Index (MAI) dietary measures

Assesses overall diet pattern based on traditional Mediterranean diet

Assesses how close the population's food intake meets reference dietary pattern. This version is varied slightly with respect to the original $^{(37)}$ related recommendations

Eight desirable components including: high monounsaturated to saturated fat ratio; high legume consumption; high vegetable consumption; high fruit consumption; high cerea consumption; moderate ethanol consumption; low milk/ dairy consumption; low meat/meat product consumption. Cut-off points were used for each component based on median values for each sex. 1 point for each component met, score range 0-8. Higher scores indicate better diet

Similar to previous MDS; however fish added as a componen making a total of nine. Beneficial components (legumes, fruit/nuts, vegetables, cereals and fish) received score of 1 if above the sex-specific median cut-off, and 0 if below median. For detrimental components (dairy, meat and poultry), a score of 1 received if below median and 0 if above. In ethanol component, 1 point received for men who consume 10-50 g/d and for women who consume 5-25 g/d The last component is ratio of monounsaturated fat to saturated fat. Score range is $0-9$, with 9 indicating maximal adherence to traditional Mediterranean diet

Similar to previous MDS, only seven components as high legume consumption was omitted, and starchy roots were placed in vegetable group not the cereals as above. Score range 0-7, with 7 indicating better diet

Similar to original MDS but has nine components. The legumes group was replaced with legumes/nuts/seeds; the vegetable group replaced with vegetable and potatoes; and the meat and meat products group replaced with meat and poultry. Fish was also added as a group. Score range from 0 to 9 , with 9 indicating a higher quality diet

The sum of Mediterranean food groups divided by the sum of non-Mediterranean food groups. Mediterranean foods include cereals; legumes; vegetables; fruit; potatoes; fish; mono-

unsaturated fat; wine. Non-Mediterranean foods include milk and its products; meat and poultry; eggs; sugar; saturated fat Original version used vegetable oil instead of monounsaturated, and animal fats and margarine instead of saturated fat In the original version food groups are expressed as

percentage of total daily intake of energy; however, this was

$3 \mathrm{~d}$ food record and frequency checklist

Diet history Trichopoulou et al. (1995) $)^{(12)}$ FQ (150 items) Trichopoulou et al. $(2003)^{(17)}$ Lagiou et al. (2006)

changed to adjusted daily intakes for men and women 


\begin{tabular}{|c|c|c|c|c|}
\hline Index & Objective & Index method & Dietary method & Study and reference \\
\hline $\begin{array}{l}\text { Alternative } \\
\text { Mediterranean } \\
\text { Diet Score (aMed) }\end{array}$ & $\begin{array}{l}\text { Assesses overall diet pattern based on } \\
\text { traditional Mediterranean diet }\end{array}$ & $\begin{array}{l}\text { Variation of original MDS. Components have been modified: } \\
\text { potato products excluded from vegetable group; fruits and } \\
\text { nuts separated into two groups; dairy group eliminated; } \\
\text { includes whole-grain products only; includes only red and } \\
\text { processed meats for the meat group; and assigning } 1 \text { point } \\
\text { for } 5 \text { and } 15 \mathrm{~g} / \mathrm{d} \text { alcohol intake. Scoring system as } \mathrm{MDS}^{(4)} \text {. } \\
\text { The score range is } 0-9 \text {, with } 9 \text { indicating better diet }\end{array}$ & $\begin{array}{l}\text { FFQ (61 expanded } \\
\text { to } 116 \text { items) }\end{array}$ & Fung et al. $(2006)^{(21)}$ \\
\hline $\begin{array}{l}\text { Total and specific } \\
\text { food group } \\
\text { diversity (1) }\end{array}$ & Assesses variety of food intake & $\begin{array}{l}\text { Based on total number of foods consumed at least once } \\
\text { weekly. Quartiles of total diversity and specific food group } \\
\text { diversity formed based on distribution of controls including } \\
\text { age and sex. Highest quartile indicates more diversity in the } \\
\text { diet. Food groups included: vegetables; fruit; meat; } \\
\text { carbohydrate; other food }\end{array}$ & FFQ (29 items) & Fernandez et al. $(1996)^{(26)}$ \\
\hline $\begin{array}{l}\text { Total and specific } \\
\text { food group } \\
\text { diversity, and diet } \\
\text { composition }\end{array}$ & $\begin{array}{l}\text { Assesses variety of food intake and composition } \\
\text { of diet (proportion of food categories) }\end{array}$ & $\begin{array}{l}\text { Diet diversity defined by number of unique foods reported in } \\
\text { past year, in addition to diversity within six food groups. Six } \\
\text { groups include: meat/fish/poultry/eggs; fruits; vegetables; } \\
\text { whole grains; refined grains; dairy foods. Composition } \\
\text { defined by estimated proportion of total food items reported } \\
\text { in each food group, as well as ratio of plant to animal } \\
\text { products. Gender-specific quintiles were produced for diet } \\
\text { diversity and composition in the control group. Did not } \\
\text { specify calculation of score }\end{array}$ & Diet history & Slattery et al. (1997) \\
\hline $\begin{array}{l}\text { Total and specific } \\
\text { food group } \\
\text { diversity (2) }\end{array}$ & Assesses variety of food intake & $\begin{array}{l}\text { Based on total number of foods consumed at least once } \\
\text { weekly. Quartiles of total diversity and specific food group } \\
\text { diversity formed based on distribution of controls including } \\
\text { age and sex. Highest quartile indicates more diversity in the } \\
\text { diet. Food groups included: dairy; bread and cereal; meat; } \\
\text { vegetables; fruit }\end{array}$ & FFQ (79 items) & Fernandez et al. (2000) \\
\hline
\end{tabular}


Table 2 Quality assessment of included studies

\begin{tabular}{|c|c|c|c|c|c|}
\hline Study and reference & $\begin{array}{c}\text { Was the study based on a } \\
\text { random or pseudo-random } \\
\text { sample? }\end{array}$ & $\begin{array}{c}\text { Were inclusion criteria } \\
\text { for the sample clearly } \\
\text { defined? }\end{array}$ & $\begin{array}{l}\text { Were outcomes } \\
\text { assessed } \\
\text { objectively? }\end{array}$ & $\begin{array}{l}\text { Were group } \\
\text { descriptions sufficient } \\
\text { for comparisons? }\end{array}$ & Was the statistical analysis appropriate?* \\
\hline Trichopoulou et al. (1995) ${ }^{(12)}$ & $\mathrm{U}$ & $\mathrm{N}$ & $\mathrm{N}$ & $\mathrm{N}$ & $\mathrm{CPH}$; rate ratios \\
\hline Fernandez et al. (1996) $)^{(26)}$ & $\mathrm{N}$ & Y & $\mathrm{U}$ & Y & $\begin{array}{l}\text { OR from unconditional multiple logistic } \\
\text { regression }\end{array}$ \\
\hline Murphy et al. (1996) ${ }^{(34)}$ & $\mathrm{N}$ & $\mathrm{N}$ & $\mathrm{Y}$ & $\mathrm{N}$ & $\mathrm{CPH}$ \\
\hline Huijbregts et al. (1997) ${ }^{(7)}$ & U - previously published & U & $\mathrm{Y}$ & $\mathrm{Y}$ & $\mathrm{CPH}$ \\
\hline Osler and Scroll (1997) ${ }^{(19)}$ & $\mathrm{Y}$ & $\mathrm{N}$ & $\mathrm{Y}$ & $\mathrm{N}$ & $\mathrm{CPH}$; rate ratio \\
\hline Slattery et al. (1997) $)^{(27)}$ & $\mathrm{N}$ & $\mathrm{Y}$ & $\mathrm{Y}$ & $\mathrm{Y}$ & $\begin{array}{l}\text { OR from unconditional multiple logistic } \\
\text { regression models }\end{array}$ \\
\hline Huijbregts et al. $(1998)^{(29)}$ & U - previously published & $U$ & $\mathrm{Y}$ & $U$ & OR from multiple logistic regression \\
\hline Fernandez et al. $(2000)^{(25)}$ & $\mathrm{N}$ & $\mathrm{N}$ & $\mathrm{N}$ & $\mathrm{N}$ & $\begin{array}{l}\text { OR from unconditional multiple logistic } \\
\text { regression }\end{array}$ \\
\hline Gerber et al. $(2000)^{(14)}$ & $\mathrm{N}$ & $\mathrm{N}$ & $\mathrm{Y}$ & $\mathrm{N}$ & $\begin{array}{l}\text { Wilcoxon signed rank test; Spearman rank } \\
\text { correlations }\end{array}$ \\
\hline Kant et al. $(2000)^{(9)}$ & $\mathrm{N}$ & Y & $\mathrm{Y}$ & $\mathrm{N}$ & $\mathrm{CPH}$ \\
\hline McCullough et al. (2000) & $\mathrm{N}$ & $\mathrm{N}$ & $\mathrm{Y}$ & $\mathrm{N}$ & RR from pooled logistic regression \\
\hline McCullough et al. (2000) (24) & $\mathrm{N}$ & $\mathrm{Y}$ & $\mathrm{Y}$ & $\mathrm{Y}$ & RR from pooled logistic regression \\
\hline Hann et al. $(2001)^{(6)}$ & $\mathrm{N}$ & $\mathrm{Y}$ & $\mathrm{Y}$ & $\mathrm{Y}$ & Pearson correlations; stepwise regression \\
\hline Osler et al. $(2001)^{(8)}$ & $\mathrm{Y}$ & $\mathrm{U}$ & $\mathrm{Y}$ & $\mathrm{U}$ & $\mathrm{CPH}$; hazard rate ratio \\
\hline Fitzgerald et al. (2002) ${ }^{(11)}$ & Y - previously published & U & $\mathrm{Y}$ & $\mathrm{Y}$ & OR from logistic regression \\
\hline Harnack et al. (2002) & $\mathrm{Y}$ & $\mathrm{Y}$ & $\mathrm{Y}$ & $\mathrm{Y}$ & $\mathrm{CPH}$; relative risk \\
\hline McCullough et al. (2002)(22) & U & $\mathrm{N}$ & $\mathrm{Y}$ & $\mathrm{Y}$ & OR from logistic regression \\
\hline Michels and Wolk (2002) & $\mathrm{N}$ & $\mathrm{Y}$ & $\mathrm{N}$ & $\mathrm{Y}$ & $\mathrm{CPH}$; hazard ratios \\
\hline Osler et al. (2002) & $\mathrm{Y}$ & $\mathrm{N}$ & $\mathrm{Y}$ & $\mathrm{Y}$ & $\mathrm{CPH}$; hazard rate ratio \\
\hline Seymour et al. $(2003)^{(10)}$ & $\mathrm{N}$ & $\mathrm{Y}$ & $\mathrm{Y}$ & $\mathrm{Y}$ & $\mathrm{CPH}$; hazard rate ratio \\
\hline Trichopoulou et al. (2003) ${ }^{(17)}$ & $\mathrm{U}$ & $\mathrm{Y}$ & $\mathrm{Y}$ & $\mathrm{N}$ & $\mathrm{CPH}$; hazard rate ratio \\
\hline Weinstein et al. $(2004)^{(13)}$ & $\mathrm{Y}$ & $\mathrm{Y}$ & $\dot{Y}$ & $\mathrm{~N}$ & $\begin{array}{l}\text { Weighted Pearson correlations; multiple linear } \\
\text { regression }\end{array}$ \\
\hline Mai et al. $(2005)^{(32)}$ & $\mathrm{N}$ & Y & $\mathrm{Y}$ & Y & $\mathrm{CPH}$; relative risk \\
\hline Bazelmans et al. $(2006)^{(31)}$ & Y & $\mathrm{N}$ & $\mathrm{Y}$ & $\mathrm{N}$ & $\begin{array}{l}\text { Mann-Whitney tests; } t \text { tests; Pearson's } \chi^{2} \text { tests; } \\
\text { logistic regression }\end{array}$ \\
\hline Fung et al. (2006) $)^{(21)}$ & $\mathrm{U}$ & $U$ & $\mathrm{Y}$ & $\mathrm{U}$ & $\mathrm{CPH}$; relative risk \\
\hline Knoops et al. $(2006)^{(20)}$ & U - previously published & $\mathrm{U}$ & $\mathrm{Y}$ and $\mathrm{N}$ & $\mathrm{Y}$ & $\mathrm{CPH}$; hazard rate ratio \\
\hline Lagiou et al. $(2006)^{(18)}$ & Y & U & Y & $\mathrm{Y}$ & $\mathrm{CPH}$; hazard rate ratio \\
\hline Toft et al. $(2007)^{(15)}$ & $\mathrm{Y}$ & $\mathrm{Y}$ & $\mathrm{Y}$ & $\mathrm{N}$ & $\begin{array}{l}\text { Spearman's correlations; ordinal logistic } \\
\text { regression; linear and multiple regression }\end{array}$ \\
\hline Total & $9 \mathrm{Y}, 7 \mathrm{U}, 12 \mathrm{~N}$ & $12 \mathrm{Y}, 7 \mathrm{U}, 9 \mathrm{~N}$ & 23/24Y, 1U, 3/4N & $14 \mathrm{Y}, 3 \mathrm{U}, 11 \mathrm{~N}$ & $28 Y^{\circ}$ \\
\hline
\end{tabular}

$\mathrm{U}$, unclear; N, no; Y, yes; $\mathrm{CPH}$, Cox proportional hazard model.

${ }^{*}$ All studies Yes for statistical tests. 
Table 3 Cross-sectional validation studies of diet quality scores with biomarkers and biological outcomes

\begin{tabular}{|c|c|c|c|c|c|c|}
\hline $\begin{array}{l}\text { Study and } \\
\text { reference }\end{array}$ & Index & $\begin{array}{l}\text { Dietary } \\
\text { method }\end{array}$ & Subjects & Main outcome & Results & Limitations \\
\hline $\begin{array}{l}\text { Huijbregts et al. } \\
\qquad(1998)^{(29)}\end{array}$ & HDI & Diet history & $\begin{array}{l}1049 \text { men aged } 70-91 \\
\text { years. Seven } \\
\text { Countries Study: } \\
\text { Finland, Italy and The } \\
\text { Netherlands }\end{array}$ & $\begin{array}{l}\text { Cognitive function. } \\
\text { Measured by MMSE }\end{array}$ & $\begin{array}{l}\text { One of five cohorts suggested higher } \\
\mathrm{HDI}=\text { statistically significant lower } \\
\text { prevalence of cognitive impairment. } \\
\text { Variation in prevalence of cognitive } \\
\text { impairment: } 14.4 \% \text { in The Netherlands } \\
\text { to } 42 \cdot 1 \% \text { in one cohort in Italy }\end{array}$ & $\begin{array}{l}\text { Cross-sectional design with dietary data } \\
\text { collected retrospectively after } 30 \text {-year } \\
\text { follow-up } \\
\text { Variation in cohort participation rates } \\
\text { Possible differences in precision of dietary } \\
\text { reporting associated with cognitive function }\end{array}$ \\
\hline $\begin{array}{l}\text { Gerber et al. } \\
(2000)^{(14)}\end{array}$ & DQI (2) & $\begin{array}{l}\text { 162-item } \\
\text { FFQ }\end{array}$ & $\begin{array}{c}146 \text { adults aged } 22-75 \\
\text { years. South France }\end{array}$ & $\begin{array}{l}\text { Plasma carotenoid and } \\
\text { vitamin E; plasma TAG } \\
\text { and cholesterol; fatty } \\
\text { acids in erythrocyte } \\
\text { membranes }\end{array}$ & $\begin{array}{l}\text { Poor diets had lower EPA, DHA, vitamin E } \\
\text { and } \beta \text {-carotene concentrations and higher } \\
\text { cholesterol concentrations. DQI } \\
\text { significantly correlated only with EPA } \\
\text { and DHA; vitamin E borderline significant. } \\
\text { After adjustment for smoking, DQI } \\
\text { significantly correlated with EPA, DHA, } \\
\text { vitamin E and } \beta \text {-carotene }\end{array}$ & $\begin{array}{l}\text { Items and score limits used in DQI limit } \\
\text { application of tool on various populations } \\
\text { Fat recommendation }(<30 \%) \text { not suitable for } \\
\text { population studied } \\
\text { Cross-sectional design of the study } \\
\text { Small cohort }\end{array}$ \\
\hline $\begin{array}{l}\text { Hann et al. } \\
\qquad(2001)^{(6)}\end{array}$ & $\mathrm{HEI}$ & $\begin{array}{l}3 d \text { food } \\
\text { record }\end{array}$ & $\begin{array}{l}340 \text { women aged } \\
21-80 \text { years. USA }\end{array}$ & $\begin{array}{l}\text { Carotenoids, vitamin } \mathrm{C} \text {, } \\
\text { folate and cholesterol }\end{array}$ & $\begin{array}{l}\text { HEI correlated with plasma carotenoids } \\
\text { (except lycopene), folate and vitamin C } \\
\text { level }\end{array}$ & $\begin{array}{l}\text { Possible confounding factors include: income } \\
\text { level, education level, economics of food } \\
\text { choice } \\
\text { Cross-sectional design of the study } \\
\text { Small cohort }\end{array}$ \\
\hline $\begin{array}{l}\text { Weinstein et al. } \\
\qquad(2004)^{(13)}\end{array}$ & $\mathrm{HEI}$ & $24 \mathrm{~h}$ recall & $\begin{array}{l}16467 \text { adults aged }>17 \\
\text { years. NHANES III, } \\
\text { USA }\end{array}$ & $\begin{array}{l}\text { Serum vitamins } A, B_{12} \text {, } \\
C, D \text { and } E ; R B C \text { and } \\
\text { serum folate; serum } \\
\text { carotenoids, ferritin, Se, } \\
\text { TAG, homocysteine } \\
\text { and cholesterol }\end{array}$ & $\begin{array}{l}\text { HEI had positive correlation with RBC and } \\
\text { serum folate, serum vitamin C and E, and } \\
\text { serum carotenoids (except lycopene). } \\
\text { Results were } 21-175 \% \text { higher in highest } \\
\text { HEI group. Strongest associations } \\
\text { occurred in biomarkers of vegetable and } \\
\text { fruit consumption. Mean HEl significantly } \\
\text { higher in those who consumed dietary } \\
\text { supplements ( } 42 \% \text { of participants). Partial } \\
\text { correlations became attenuated once } \\
\text { compared with crude correlations }\end{array}$ & $\begin{array}{l}\text { Biomarkers used were limited as represent } \\
\text { nutrients found in vegetables and fruit, } \\
\text { therefore does not reflect whole diet } \\
\text { Use of } 24 \mathrm{~h} \text { recall as dietary measure } \\
\text { Possible confounding due to supplement use } \\
\text { Cross-sectional design of the study }\end{array}$ \\
\hline $\begin{array}{l}\text { Toft et al. } \\
(2007)^{(15)}\end{array}$ & DQS (2) & $\begin{array}{l}\text { 48-item FFQ } \\
\text { (validated } \\
\text { by 198- } \\
\text { item FFQ) }\end{array}$ & $\begin{array}{l}6542 \text { men and women } \\
\text { aged } 30-60 \text { years. } \\
\text { Inter99 study, } \\
\text { Denmark }\end{array}$ & $\begin{array}{l}\text { Total cholesterol, TAG, } \\
\text { HDL-C, LDL-C, } \\
\text { homocysteine and } \\
\text { blood pressure } \\
\text { Risk of IHD estimated } \\
\text { by Copenhagen Risk } \\
\text { Score }\end{array}$ & $\begin{array}{l}\text { DQS had negative association with total } \\
\text { cholesterol, LDL-C, TAG, homocysteine } \\
\text { and absolute risk of IHD (adjusted for age, } \\
\text { sex, physical activity level and smoking). } \\
\text { DQS had positive association with HDL-C }\end{array}$ & $\begin{array}{l}\text { Similarity in two FFQ used may have caused } \\
\text { overestimation of score validity; however, } \\
\text { different time period measures in two FFQ } \\
\text { may have caused underestimation of score } \\
\text { validity } \\
\text { Cross-sectional design of the study }\end{array}$ \\
\hline
\end{tabular}


Scoring methods and cut-off points to assess diet quality vary across indices. The various MDS indices use sexspecific median cut-off points ${ }^{(12,17-21)}$. Median cut-off points allow subjects to be scored positively or negatively for each item ${ }^{(3)}$. Indices such as the Dietary Guidelines Index (DGI) ${ }^{(28)}$ use lower, intermediate and upper cut-off levels ${ }^{(3)}$, while the HDI uses dichotomous values to determine whether dietary recommendations have been met or not. For example, with the HDI, if a person consumed $27-40 \mathrm{~g}$ dietary fibre daily, he/she was awarded 1 point for the recommendation being met $^{(3)}$. It is debatable whether cut-off boundaries, dichotomous values or continuous variables allow for a better evaluation of adherence to recommendations or examination of associations with disease outcomes.

\section{Health outcomes associated with diet quality indices}

Diet quality indices can also be used to measure risk of various health outcomes, including biomarkers of disease (Table 3), mortality and chronic diseases (Tables 4 and 5). These are discussed by major dietary index type to allow better comparison of the study results.

\section{Healthy Eating Index}

The HEI was used in three studies ${ }^{(6,13,21)}$ and was associated with biomarkers such as carotenoids (except lycopene), cholesterol and vitamins $\mathrm{C}$ and $\mathrm{E}^{(6,13)}$. The strongest associations occurred for the biomarkers of vegetable and fruit consumption ${ }^{(6,13,21)}$. Mean HEI was significantly higher in the $42 \%$ of participants who consumed dietary supplements ${ }^{(13)}$. In one study, the HEI was used among various other indices (AHEI, DQI-R, RFS and aMED) to measure incidence of breast cancer ${ }^{(21)}$. However, it was shown to have limited ability to predict risk for oestrogen receptor (ER)-negative breast cancer ${ }^{(21)}$.

An Alternative HEI (AHEI) was used in two studies, with varied associations with cancer incidence ${ }^{(21,22)}$. It did not predict all-site cancer risk in a study of US adults ${ }^{(22)}$ but was inversely associated with chronic disease risk in men and women $(39 \%$ and $28 \%$ reduced CVD risk in the highest AHEI quintile for men and women, respectively, with a weaker relationship in women). AHEI was associated with lower risk of ER-negative breast cancer in a study of postmenopausal women, with an $11 \%$ reduction in risk for each $10 \%$ increase in score ${ }^{(21)}$.

HEI derived from an FFQ (HEI-f) was used in two studies ${ }^{(23,24)}$. HEI-f was associated with an $11 \%$ reduction in major chronic disease risk in men, but not women. These studies also found a reduced CVD risk in men (28\%) and women (14\%), but there were no associations with reduced cancer risk ${ }^{(23,24)}$.

\section{Healthy Diet Indicator}

The HDI was used in three studies ${ }^{(7,20,29)}$. One study used cognitive function as the outcome measure and found in 
Table 5 Prospective cohort studies with mortality and morbidity as outcome, ordered by increasing length of follow-up

\begin{tabular}{|c|c|c|c|c|c|c|c|}
\hline $\begin{array}{l}\text { Study and } \\
\text { reference }\end{array}$ & Index & $\begin{array}{l}\text { Dietary } \\
\text { method }\end{array}$ & Subjects & Main outcome & Key findings & Mortality results & Limitations \\
\hline $\begin{array}{l}\text { Trichopoulou } \\
\text { et al. }(2003)^{(17)}\end{array}$ & MDS (2) & $\begin{array}{l}\text { 150-item } \\
\text { FFQ }\end{array}$ & $\begin{array}{l}22043 \text { adults aged } \\
20-86 \text { years. EPIC, } \\
\text { Greece }\end{array}$ & $\begin{array}{l}\text { Mortality: all-cause, } \\
\text { all-site cancer } \\
\text { and CHD }\end{array}$ & $\begin{array}{l}\text { After } 3 \cdot 7 \text {-year follow-up MDS } \\
\text { associated with reduced total } \\
\text { mortality; } 2 \text {-point increase in score } \\
\text { led to } 25 \% \text { reduction. MDS } \\
\text { inversely associated with mortality } \\
\text { due to CHD and cancer }\end{array}$ & $\begin{array}{l}\text { Cox proportional hazard model. } \\
\text { Relative hazard }(95 \% \mathrm{Cl}) \text { of death } \\
\text { for } 2 \text {-point increment in MDS } \\
\text { All-cause mortality } \\
\text { Age/sex adj: } 0.79(0.69,0.91) \\
\text { All adj: } 0.75(0.64,0.87)\end{array}$ & $\begin{array}{l}\text { Possible residual } \\
\text { confounding by } \\
\text { unevaluated factors } \\
\text { Short follow-up period } \\
\text { for mortality outcome }\end{array}$ \\
\hline $\begin{array}{l}\text { Trichopoulou } \\
\text { et al. }(1995)^{(12)}\end{array}$ & MDS (1) & $\begin{array}{l}\text { 1980-item } \\
\text { FFQ }\end{array}$ & $\begin{array}{l}182 \text { older adults aged } \\
>70 \text { years. Greece }\end{array}$ & $\begin{array}{l}\text { All-cause mortality: } \\
\text { survival beyond } \\
70 \text { years of age }\end{array}$ & $\begin{array}{l}\text { After } 4 \text {-year follow-up MDS inversely } \\
\text { associated with all-cause mortality. } \\
\text { For every } 1 \text {-unit increase in score } \\
\text { (maximum } 8 \text { points) all-cause } \\
\text { mortality was significantly reduced } \\
\text { by } 17 \%\end{array}$ & $\begin{array}{l}\text { Cox proportional hazard model } \\
\text { adjusted for age, sex, smoking } \\
\text { and diet score } \\
\text { For each unit increase in diet score, } \\
\text { death rate ratio }(95 \% \mathrm{Cl})=0.83 \\
(0.69,0.99) \\
\text { For men, relative to women, death } \\
\text { rate ratio }(95 \% \mathrm{Cl})=1.06(0.55 \text {, } \\
2.03)\end{array}$ & $\begin{array}{l}\text { Small cohort } \\
\text { Short follow-up period } \\
\text { for mortality outcome } \\
\text { Study duration may not } \\
\text { have been long } \\
\text { enough to capture } \\
\text { latency period } \\
\text { needed to detect diet } \\
\text { and cancer risk } \\
\text { associations }\end{array}$ \\
\hline $\begin{array}{l}\text { Seymour et al. } \\
\quad(2003)^{(10)}\end{array}$ & DQI (1) & $\begin{array}{c}\text { 68-item } \\
\text { FFQ }\end{array}$ & $\begin{array}{l}63109 \text { women and } \\
52724 \text { men aged } \\
50-79 \text { years. } \\
\text { American Cancer } \\
\text { Society Cancer } \\
\text { Prevention Study II } \\
\text { Nutrition Cohort. USA }\end{array}$ & $\begin{array}{l}\text { Mortality: short- } \\
\text { term all-cause, } \\
\text { circulatory and } \\
\text { cancer }\end{array}$ & $\begin{array}{l}\text { After 4-year follow-up DQI positively } \\
\text { associated with all-cause and } \\
\text { circulatory disease mortality in men } \\
\text { and women, and cancer mortality in } \\
\text { men only; when adjusted for } \\
\text { multiple covariates relationship } \\
\text { positive only for circulatory disease } \\
\text { mortality in women. DQI unrelated } \\
\text { to cancer mortality }\end{array}$ & $\begin{array}{l}\text { Cox proportional hazard model. } \\
\text { Death rate ratio }(95 \% \mathrm{Cl}) \text { for low } \\
\text { diet quality } v \text {. high } \\
\text { All-cause mortality } \\
\text { Age adj: } 1 \cdot 86(1 \cdot 28,2 \cdot 70) \\
\text { All adj: } 1 \cdot 23(0 \cdot 84,1 \cdot 81) \\
\text { All circulatory disease } \\
\text { Age adj: } 2 \cdot 26(1 \cdot 12,4 \cdot 54) \\
\text { All adj: } 1 \cdot 81(0 \cdot 88,3 \cdot 72) \\
\text { All cancer } \\
\text { Age adj: } 0.93(0 \cdot 49,1 \cdot 77) \\
\text { All adj: } 0 \cdot 61(0 \cdot 32,1 \cdot 18)\end{array}$ & $\begin{array}{l}\text { Limitations of DQI } \\
\text { Short follow-up period } \\
\quad \text { for mortality outcome }\end{array}$ \\
\hline $\begin{array}{l}\text { Kant et al. } \\
(2000)^{(9)}\end{array}$ & RFS & $\begin{array}{c}\text { 62-item } \\
\text { FFQ }\end{array}$ & $\begin{array}{l}42254 \text { women, mean } \\
\text { age } 61 \text { years. Breast } \\
\text { Cancer Detection } \\
\text { Demonstration } \\
\text { Project. USA }\end{array}$ & All-cause mortality & $\begin{array}{l}\text { After } 5 \cdot 6 \text {-year follow-up RFS } \\
\text { inversely related to all-cause and } \\
\text { cause-specific mortality. } 30 \% \\
\text { lower all-cause and cause-specific } \\
\text { mortality in highest RFS quartile } \\
\text { (age- and multivariate-adjusted) }\end{array}$ & $\begin{array}{l}\text { Cox proportional hazard model. } \\
\text { Relative risk }(95 \% \mathrm{CI}) \text { for low (Q1) } \\
\text { diet quality } v \text {. high }(\mathrm{Q} 4) \text { after } \\
\text { exclusion for baseline disease } \\
\text { All-cause mortality } \\
\text { Age adj: } 0.55(0.45,0.66) \\
\text { Multivariate adj: } 0.66(0.56,0.82)\end{array}$ & $\begin{array}{l}\text { Generalising of results } \\
\text { limited as cohort } \\
\text { participants were } \\
\text { from a screening } \\
\text { study }\end{array}$ \\
\hline $\begin{array}{l}\text { Osler and } \\
\text { Schroll } \\
(1997)^{(19)}\end{array}$ & MDS (3) & $\begin{array}{l}3 \mathrm{~d} \text { food } \\
\text { record and } \\
\text { frequency } \\
\text { checklist }\end{array}$ & $\begin{array}{l}202 \text { adults, mean age } \\
>70 \text { years. Denmark }\end{array}$ & All-cause mortality & $\begin{array}{l}\text { After 6-year follow-up MDS inversely } \\
\text { associated with all-cause mortality. } \\
\text { A 1-unit increase in } 7 \text {-point score } \\
\text { reduced mortality by } 21 \% \text {. Plasma } \\
\text { carotene levels significantly higher } \\
\text { in subjects with high diet scores; } \\
\text { plasma carotene negatively } \\
\text { associated with mortality }\end{array}$ & $\begin{array}{l}\text { Cox proportional hazard model } \\
\text { For each unit increase in diet score, } \\
\text { death rate ratio }(95 \% \mathrm{Cl})=0.79 \\
(0.64,0.98) \\
\text { For women, relative to men, death } \\
\text { rate ratio }(95 \% \mathrm{Cl})=0.98(0.54 \text {, } \\
1.80)\end{array}$ & $\begin{array}{l}\text { Small cohort } \\
\text { Study duration may not } \\
\text { have been long } \\
\text { enough to capture } \\
\text { latency period } \\
\text { needed to detect diet } \\
\text { and cancer risk } \\
\text { associations }\end{array}$ \\
\hline
\end{tabular}


Table 5 Continued

\begin{tabular}{|c|c|c|c|c|c|c|c|}
\hline $\begin{array}{l}\text { Study and } \\
\text { reference }\end{array}$ & Index & $\begin{array}{l}\text { Dietary } \\
\text { method }\end{array}$ & Subjects & Main outcome & Key findings & Mortality results & Limitations \\
\hline $\begin{array}{l}\text { McCullough } \\
\quad \text { et al. } \\
(2000)^{(23)}\end{array}$ & HEl-f & $\begin{array}{c}\text { 131-item } \\
\text { FFQ }\end{array}$ & $\begin{array}{l}51529 \text { men aged } \\
40-75 \text { years. Health } \\
\text { Professionals' } \\
\text { Follow-Up Study. } \\
\text { USA }\end{array}$ & $\begin{array}{l}\text { Major chronic } \\
\text { disease: } \\
\text { incidence and } \\
\text { mortality. Primary } \\
\text { endpoint defined } \\
\text { as non-fatal or } \\
\text { fatal CVD, cancer } \\
\text { or death (non } \\
\text { trauma-related) }\end{array}$ & $\begin{array}{l}\text { After 8-year follow-up HEl-f had weak } \\
\text { inverse association with risk of } \\
\text { major chronic disease (multiple } \\
\text { covariate adjustment). } 28 \% \text { lower } \\
\text { risk of CVD between highest and } \\
\text { lowest HEl-f quintiles. } 11 \% \\
\text { reduction in risk of developing } \\
\text { CVD. No association with reduced } \\
\text { cancer risk }\end{array}$ & $\begin{array}{l}\text { Cox proportional hazard model. } \\
\text { Relative risk }(95 \% \mathrm{Cl}) \text { for low }(\mathrm{Q} 1) \\
\text { diet quality } v \text {. high (Q5) } \\
\text { Major chronic disease } \\
\text { Age adj: } 0 \cdot 84(0 \cdot 75,0 \cdot 94) \\
\text { Multivariate adj: } 0.89(0 \cdot 79,1 \cdot 00)\end{array}$ & $\begin{array}{l}\text { Study duration may not } \\
\text { have been long } \\
\text { enough to capture } \\
\text { latency period } \\
\text { needed to detect diet } \\
\text { and cancer risk } \\
\text { associations } \\
\text { Some HEl-f } \\
\text { components weaken } \\
\text { associations with } \\
\text { chronic disease } \\
\text { outcomes } \\
\text { Lack of diversity in } \\
\text { cohort population }\end{array}$ \\
\hline $\begin{array}{l}\text { McCullough } \\
\text { et al. } \\
(2002)^{(22)}\end{array}$ & $\begin{array}{l}\text { RFS } \\
\text { AHEl }\end{array}$ & $\begin{array}{l}\sim 130 \text {-item } \\
\text { FFQ }\end{array}$ & $\begin{array}{l}67271 \text { women and } \\
38615 \text { men. Health } \\
\text { Professionals' } \\
\text { Follow-Up Study and } \\
\text { Nurses' Health } \\
\text { Study. USA }\end{array}$ & $\begin{array}{l}\text { Major chronic } \\
\text { disease defined } \\
\text { as initial } \\
\text { occurrence of } \\
\text { cancer, CVD or } \\
\text { non-traumatic } \\
\text { death }\end{array}$ & $\begin{array}{l}\text { After 8-12-year follow-up RFS and } \\
\text { AHEI inversely related with chronic } \\
\text { disease risk in men (covariate- } \\
\text { adjusted). Men in highest AHEI } \\
\text { quintile had } 39 \% \text { reduced risk of } \\
\text { CVD v. lowest, while men in } \\
\text { highest RFS quintile had } 23 \% \\
\text { lower CVD risk (multivariate- } \\
\text { adjusted). AHEl showed weak but } \\
\text { significant inverse relationship with } \\
\text { chronic disease risk in women; } 28 \% \\
\text { lower CVD risk comparing highest } \\
\text { AHEI quintile with lowest. RFS not } \\
\text { related to major chronic disease in } \\
\text { women. RFS and AHEI did not } \\
\text { predict cancer risk in either sex }\end{array}$ & 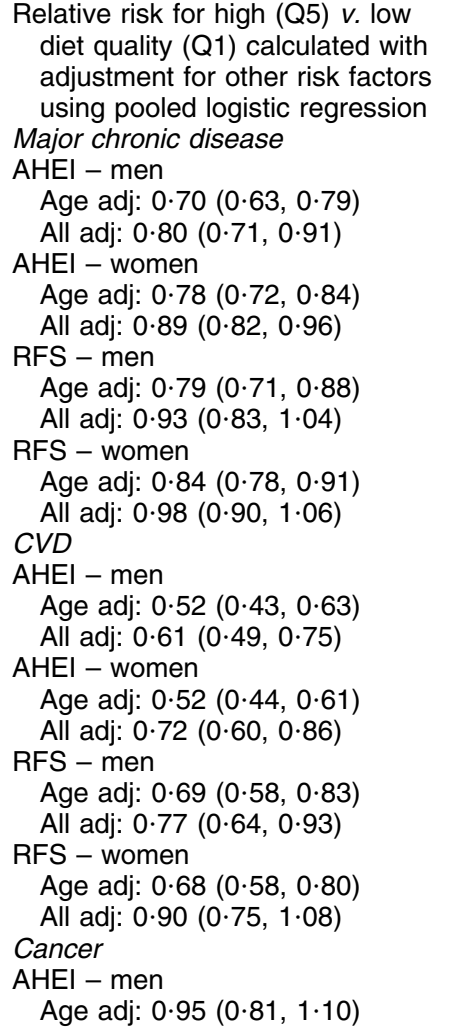 & $\begin{array}{l}\text { Lack of diversity in } \\
\text { cohort population } \\
\text { Possible confounder in } \\
\text { the selection of a } \\
\text { relatively health- } \\
\text { conscious population }\end{array}$ \\
\hline
\end{tabular}




\begin{tabular}{|c|c|c|c|c|c|c|c|}
\hline $\begin{array}{l}\text { Study and } \\
\text { reference }\end{array}$ & Index & $\begin{array}{l}\text { Dietary } \\
\text { method }\end{array}$ & Subjects & Main outcome & Key findings & Mortality results & Limitations \\
\hline & & & & & & $\begin{array}{l}\text { All adj: } 1.03(0.87,1.22) \\
\text { AHEI - women } \\
\text { Age adj: } 0.91(0.83,0.99) \\
\text { All adj: } 0.97(0.88,1.06) \\
\text { RFS - men } \\
\text { Age adj: } 0.95(0.82,1.10) \\
\text { All adj: } 1.08(0.94,1.25) \\
\text { RFS - women } \\
\text { Age adj: } 0.92(0.85,1.01) \\
\text { All adj: } 1.00(0.92,1.11)\end{array}$ & \\
\hline $\begin{array}{l}\text { Fitzgerald et al. } \\
\qquad(2002)^{(11)}\end{array}$ & DQS (1) & $24 \mathrm{~h}$ recall & $\begin{array}{l}2108 \text { adults aged } \\
18-74 \text { years. Canada }\end{array}$ & $\begin{array}{l}\text { Cancer incidence, } \\
\text { all sites }\end{array}$ & $\begin{array}{l}\text { After } 8 \cdot 3 \text {-year follow-up DQS had } \\
\text { no relationship with incidence of } \\
\text { all-sites cancer }\end{array}$ & $\begin{array}{l}\text { Logistic regression to estimate OR } \\
\text { of cancer for low (Q1) v. high } \\
\text { (Q4) diet quality } \\
\text { All cancer } \\
\text { Men } \\
\text { Age adj: } 0.83(0 \cdot 44,1 \cdot 55) \\
\text { All adj: } 0 \cdot 81(0 \cdot 40,1 \cdot 64) \\
\text { Women } \\
\text { Age adj: } 0 \cdot 74(0 \cdot 40,1 \cdot 38) \\
\text { All adj: } 0.94(0 \cdot 44,2 \cdot 00)\end{array}$ & $\begin{array}{l}\text { Study duration may not } \\
\text { have been long } \\
\text { enough to capture } \\
\text { latency period } \\
\text { needed to detect diet } \\
\text { and cancer risk } \\
\text { associations } \\
\text { Use of } 24 \mathrm{~h} \text { recall as } \\
\text { dietary measure }\end{array}$ \\
\hline $\begin{array}{l}\text { Mai et al. } \\
\quad(2005)^{(32)}\end{array}$ & RFS & $\begin{array}{l}\text { 62-item } \\
\text { FFQ }\end{array}$ & $\begin{array}{l}42254 \text { women, mean } \\
\text { age } 61 \text { years. USA }\end{array}$ & $\begin{array}{l}\text { Cancer mortality } \\
\text { and incidence: } \\
\text { breast, lung, } \\
\text { colorectal, other } \\
\text { cancers }\end{array}$ & $\begin{array}{l}\text { After } 9 \cdot 5 \text {-year follow-up RFS } \\
\text { inversely associated with total } \\
\text { mortality, cancer mortality, and } \\
\text { mortality from colorectal, lung and } \\
\text { breast cancer. Incidence of lung } \\
\text { cancer reduced in highest RFS } \\
\text { quartile }\end{array}$ & 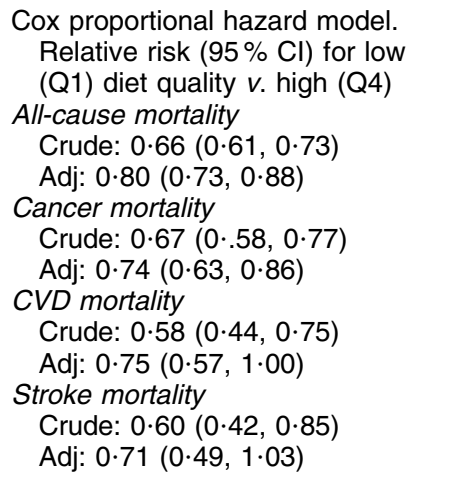 & $\begin{array}{l}\text { Possible confounders: } \\
\text { breast screening } \\
\text { habits, treatment } \\
\text { choice and lifestyle } \\
\text { factors } \\
\text { Only one FFQ over 10- } \\
\text { year follow-up }\end{array}$ \\
\hline $\begin{array}{l}\text { Michels and } \\
\text { Wolk } \\
(2002)^{(33)}\end{array}$ & $\begin{array}{l}\text { RFS } \\
\text { NRFS }\end{array}$ & $\begin{array}{l}\text { 60-item } \\
\text { FFQ }\end{array}$ & $\begin{array}{l}59038 \text { women aged } \\
40-76 \text { years. } \\
\text { Mammography } \\
\text { Screening Cohort, } \\
\text { Sweden }\end{array}$ & $\begin{array}{l}\text { Mortality: all-cause, } \\
\text { CHD, stroke and } \\
\text { cancer }\end{array}$ & $\begin{array}{l}\text { After } 9 \cdot 9 \text {-year follow-up RFS } \\
\text { inversely associated with all-cause } \\
\text { and cause-specific mortality, } \\
\text { particularly CVD and stroke. } 42 \% \\
\text { lower all-cause mortality in highest } \\
\text { RFS quintile (adjusted for multiple } \\
\text { covariates). Strong association } \\
\text { between longevity and diet quality. } \\
\text { NRFS not related to all-cause } \\
\text { mortality, CVD and stroke mortality }\end{array}$ & $\begin{array}{l}\text { Cox proportional hazard model. } \\
\text { Hazard ratios }(95 \% \text { Cl) of death } \\
\text { for highest diet quality (Q5) } v \text {. } \\
\text { lowest (Q1) } \\
\text { All-cause mortality } \\
\text { RFS } \\
\text { Age adj: } 0.54(0.46,0.62) \\
\text { All adj: } 0.58(0.50,0.68) \\
\text { NRFS } \\
\text { Age adj: } 1.02(0.84,1.23)\end{array}$ & $\begin{array}{l}\text { Quantity and frequency } \\
\text { of food consumption } \\
\text { not considered } \\
\text { Possible confounders: } \\
\text { smoking, dietary } \\
\text { supplements and PA }\end{array}$ \\
\hline
\end{tabular}


Table 5 Continued

\begin{tabular}{|c|c|c|c|c|c|c|c|}
\hline $\begin{array}{l}\text { Study and } \\
\text { reference }\end{array}$ & Index & $\begin{array}{l}\text { Dietary } \\
\text { method }\end{array}$ & Subjects & Main outcome & Key findings & Mortality results & Limitations \\
\hline & & & & & & $\begin{array}{l}\text { All adj: } 1.07(0.88,1.31) \\
\text { Cancer mortality } \\
\text { RFS } \\
\text { Age adj: } 0.71(0.56,0.89) \\
\text { All adj: } 0.76(0.60,0.96) \\
\text { NRFS } \\
\text { Age adj: } 1.40(1.05,1.86) \\
\text { All adj: } 1.52(1.13,2.05) \\
\text { CVD mortality } \\
\text { RFS } \\
\text { Age adj: } 0.43(0.30,0.61) \\
\text { All adj: } 0.47(0.33,0.68) \\
\text { NRFS } \\
\text { Age adj: } 0.79(0.48,1.32) \\
\text { All adj: } 0.79(0.47,1.32)\end{array}$ & \\
\hline $\begin{array}{l}\text { Murphy et al. } \\
(1996)^{(34)}\end{array}$ & $\mathrm{DQ}$ & $24 \mathrm{~h}$ recall & $\begin{array}{l}6249 \text { adults aged } \\
45-74 \text { years. } \\
\text { NHANES I } \\
\text { Epidemiologic } \\
\text { Follow-up Study. } \\
\text { USA }\end{array}$ & $\begin{array}{l}\text { Survival beyond } 45 \\
\text { years of age }\end{array}$ & $\begin{array}{l}\text { After } 10 \text {-year follow-up DQ inversely } \\
\text { associated with all-cause mortality } \\
\text { in males and females. Attenuated } \\
\text { by employment, health, smoking } \\
\text { and sociodemographic variables }\end{array}$ & $\begin{array}{l}\text { Cox proportional hazard model } \\
\text { adjusted for age. Relative hazard } \\
(95 \% \mathrm{Cl}) \text { of death for poor diet } \\
\text { quality } v \text {. all others } \\
\text { Men } \\
45-54 \text { years: } 1 \cdot 5(1 \cdot 0.2 \cdot 3) \\
55-64 \text { years: } 1 \cdot 9(1 \cdot 4,2 \cdot 7) \\
65-74 \text { years: } 1 \cdot 4(1 \cdot 2,1 \cdot 6) \\
\text { Women } \\
\text { 45-54 years: } 1 \cdot 5(1 \cdot 0,2 \cdot 4) \\
55-64 \text { years: } 1 \cdot 3(0 \cdot 9,1 \cdot 8) \\
65-74 \text { years: } 1 \cdot 2(1 \cdot 0,1 \cdot 4)\end{array}$ & $\begin{array}{l}\text { Use of } 24 \mathrm{~h} \text { recall as } \\
\text { dietary measure }\end{array}$ \\
\hline $\begin{array}{l}\text { Osler et al. } \\
\qquad(2002)^{(30)}\end{array}$ & $\mathrm{HFI}$ & $\begin{array}{l}\text { 26-item } \\
\text { FFQ }\end{array}$ & $\begin{array}{l}7316 \text { adults aged } \\
30-70 \text { years. } \\
\text { Denmark }\end{array}$ & $\begin{array}{l}\text { Fatal and non-fatal } \\
\text { CHD }\end{array}$ & $\begin{array}{l}\text { Follow-up varied from } 4 \text { to } 14 \text { years. } \\
\text { HFI had an insignificant, inverse } \\
\text { association with CVD risk }\end{array}$ & $\begin{array}{l}\text { Cox proportional hazard model. } \\
\text { Hazard rate ratio }(95 \% \mathrm{Cl}) \text { for CVD } \\
\text { for high }(\mathrm{Q} 4) \text { v. low }(\mathrm{Q} 1) \text { diet quality } \\
\text { Crude: } 0 \cdot 70(0 \cdot 47,1 \cdot 03) \\
\text { Adj: } 1 \cdot 21(0 \cdot 80,1 \cdot 82)\end{array}$ & $\begin{array}{l}\text { Possible dietary } \\
\text { measurement bias of } \\
\text { short FFQ }\end{array}$ \\
\hline \multicolumn{2}{|c|}{$\begin{array}{l}\text { Bazelmans et al. HFNI } \\
(2006)^{(31)}\end{array}$} & $\begin{array}{l}1 \mathrm{~d} \text { food } \\
\text { record }\end{array}$ & $\begin{array}{l}\text { Adult men and women. } \\
\text { Belgium }\end{array}$ & Mortality: all-cause & $\begin{array}{l}\text { After } 10 \text {-year follow-up HFNI } \\
\text { significantly associated with all- } \\
\text { cause mortality in men (adjusted } \\
\text { for risk factors). Risk of death } \\
\text { decreased from quartile } 1 \text { to } 4 \text {. } \\
\text { HFNI not significant in women }\end{array}$ & $\begin{array}{l}\text { OR for total mortality derived from } \\
\text { logistic regression models for low } \\
\text { (Q1) v. high (Q4) diet quality } \\
\text { Men } \\
\text { Adj age: } 1 \cdot 53(1 \cdot 10,2 \cdot 12) \\
\text { Adj all: } 1.68(1 \cdot 19,2 \cdot 37) \\
\text { Women } \\
\text { Adj age: } 1 \cdot 03(0.57,1 \cdot 82) \\
\text { Adj all: } 1.05(0 \cdot 58,1 \cdot 87)\end{array}$ & $\begin{array}{l}\text { Use of } 1 \mathrm{~d} \text { food record } \\
\text { as dietary measure } \\
\text { Scoring may not best } \\
\text { represent data } \\
\text { Lack of definition in } \\
\text { some index } \\
\text { components } \\
\text { Dietary guidelines used } \\
\text { for basis of HFNI may } \\
\text { not adequately } \\
\text { describe intake } \\
\text { associated with } \\
\text { reduced risk of } \\
\text { mortality }\end{array}$ \\
\hline
\end{tabular}




\begin{tabular}{|c|c|c|c|c|c|c|c|}
\hline $\begin{array}{l}\text { Study and } \\
\text { reference }\end{array}$ & Index & $\begin{array}{l}\text { Dietary } \\
\text { method }\end{array}$ & Subjects & Main outcome & Key findings & Mortality results & Limitations \\
\hline & & & & & & & $\begin{array}{l}\text { Study duration may not } \\
\text { have been long } \\
\text { enough to capture } \\
\text { latency period } \\
\text { needed to detect diet } \\
\text { and cancer risk } \\
\text { associations }\end{array}$ \\
\hline $\begin{array}{c}\text { Knoops et al. } \\
(2006)^{(20)}\end{array}$ & $\begin{array}{l}\text { MDS (4) } \\
\text { MAI } \\
\text { HDI }\end{array}$ & Diet history & $\begin{array}{l}\text { Elderly: } 2068 \text { men and } \\
\text { 1049 women aged } \\
\text { 70-90 years. HALE } \\
\text { study }\end{array}$ & $\begin{array}{l}\text { Mortality: all-cause, } \\
\text { CVD and other } \\
\text { causes }\end{array}$ & $\begin{array}{l}\text { After 10-year follow-up MDS, MAI } \\
\text { and HDI significantly inversely } \\
\text { related to all-cause mortality. } \\
\text { Northern Europe had higher } \\
\text { absolute mortality risk compared } \\
\text { with Southern Europe. MAI had } \\
\text { stronger association with all-cause } \\
\text { mortality in Northern Europe } \\
\text { compared with Southern Europe }\end{array}$ & $\begin{array}{l}\text { Cox proportional hazard model. } \\
\text { Hazard rate ratio }(95 \% \mathrm{Cl}) \text { for } \\
\text { high (>median) diet quality } \mathrm{v} \text {. } \\
\text { low }(<\text { median) } \\
\text { MDS } \\
\text { All adj: } 0.82(0 \cdot 75,0.91) \\
\text { All + alcohol adj: } 0.78(0.71,0.87) \\
\text { MAl } \\
\text { All adj: } 0.83(0.75,0.92) \\
\text { All + alcohol adj: } 0.87(0.79,0.97) \\
\text { HDI } \\
\text { All adj: } 0.89(0.81,0.98)\end{array}$ & $\begin{array}{l}\text { Lack of definition in } \\
\text { some index } \\
\text { components } \\
\text { Mortality associations } \\
\text { assessed in relation to } \\
\text { dichotomous ranking } \\
\text { of high and low quality } \\
\text { at the median score }\end{array}$ \\
\hline $\begin{array}{l}\text { McCullough } \\
\text { et al. } \\
(2000)^{(24)}\end{array}$ & HEl-f & $\begin{array}{l}\text { 116-item } \\
\text { FFQ }\end{array}$ & $\begin{array}{l}62722 \text { women aged } \\
30-55 \text { years. Nurses' } \\
\text { Health Study. USA }\end{array}$ & $\begin{array}{l}\text { Major chronic } \\
\text { disease: defined } \\
\text { as non-fatal or } \\
\text { fatal CVD, cancer } \\
\text { or death (non } \\
\text { trauma-related) }\end{array}$ & $\begin{array}{l}\text { After } 12-y e a r \text { follow-up HEl-f was not } \\
\text { associated with major chronic } \\
\text { disease risk (covariate-adjusted). } \\
\text { HEl-f highest quintile was } \\
\text { associated with a } 14 \% \text { lower risk } \\
\text { for CVD, with no association with } \\
\text { reduced cancer risk }\end{array}$ & $\begin{array}{l}\text { Cox proportional hazard model. } \\
\text { Relative risk }(95 \% \mathrm{Cl}) \text { for low } \\
\text { (Q1) diet quality } \mathrm{v} \text {. high }(\mathrm{Q} 5) \\
\text { Major chronic disease } \\
\text { Age adj: } 0.81(0.75,0.87) \\
\text { All adj: } 0.97(0.79,1.06) \\
\text { CVD } \\
\text { Age adj: } 0.59(0.50,0.70) \\
\text { All adj: } 0.86(0.72,1.03) \\
\text { Cancer } \\
\text { Age adj: } 0.92(0.84,1.00) \\
\text { All adj: } 1.02(0.93,1.12)\end{array}$ & $\begin{array}{l}\text { Study duration may not } \\
\text { have been long } \\
\text { enough to capture } \\
\text { latency period } \\
\text { needed to detect diet } \\
\text { and cancer risk } \\
\text { associations } \\
\text { Some HEl-f- } \\
\text { components weaken } \\
\text { associations with } \\
\text { chronic disease } \\
\text { outcomes } \\
\text { Lack of diversity in } \\
\text { cohort population }\end{array}$ \\
\hline $\begin{array}{l}\text { Lagiou et al. } \\
\qquad(2006)^{(18)}\end{array}$ & MDS (2) & $\begin{array}{c}\text { 80-item } \\
\text { FFQ }\end{array}$ & $\begin{array}{l}42237 \text { young women } \\
\text { aged } 30-49 \text { years. } \\
\text { Swedish section of } \\
\text { Scandinavian } \\
\text { Women's Lifestyle } \\
\text { and Health Cohort. } \\
\text { Sweden }\end{array}$ & $\begin{array}{l}\text { Mortality: all-cause } \\
\text { and cancer }\end{array}$ & $\begin{array}{l}\text { After } 12 \text {-year follow-up, no association } \\
\text { between women aged } 30-40 \text { years } \\
\text { at enrolment and overall or cancer } \\
\text { mortality. } 2 \text {-point increase in MDS } \\
\text { inversely associated with substantial } \\
\text { reduction in all-cause mortality ( } 23 \%) \\
\text { and cancer mortality ( } 29 \% \text { ) in women } \\
\text { aged } 40-49 \text { years at enrolment }\end{array}$ & $\begin{array}{l}\text { Cox proportional hazard model. } \\
\text { Hazard rate ratio }(95 \% \mathrm{CI}) \text { for } \\
\text { bottom third of diet quality } \mathrm{v} \text {. top } \\
\text { Total mortality } \\
\text { Age adj: } 0 \cdot 68(0.54,0 \cdot 86) \\
\text { All adj: } 0.85(0 \cdot 67,1 \cdot 08) \\
\text { Cancer mortality } \\
\text { Age adj: } 0.67(0.48,1.93) \\
\text { All adj: } 0.80(0.57,1.13)\end{array}$ & $\begin{array}{l}\text { Possible dietary } \\
\text { changes during the } \\
\text { follow-up period } \\
\text { Lack of definition in } \\
\text { some index } \\
\text { components } \\
\text { Type of alcohol not } \\
\text { defined; protective } \\
\text { benefits cannot be } \\
\text { assumed }\end{array}$ \\
\hline
\end{tabular}




\begin{tabular}{|c|c|c|c|c|c|c|c|}
\hline $\begin{array}{l}\text { Study and } \\
\text { reference }\end{array}$ & Index & $\begin{array}{l}\text { Dietary } \\
\text { method }\end{array}$ & Subjects & Main outcome & Key findings & Mortality results & Limitations \\
\hline $\begin{array}{l}\text { Harnack et al. } \\
\qquad(2002)^{(28)}\end{array}$ & DGI & $\begin{array}{l}\text { 127-item } \\
\text { FFQ }\end{array}$ & $\begin{array}{l}34708 \text { postmenopausal } \\
\text { women. Iowa, USA }\end{array}$ & $\begin{array}{l}\text { Cancer incidence } \\
\text { and mortality: all } \\
\text { cancer and site- } \\
\text { specific }\end{array}$ & $\begin{array}{l}\text { After 13-year follow-up higher DGI } \\
\text { associated with significantly lower } \\
\text { incidence of all cancers and site- } \\
\text { specific cancers. Not significant } \\
\text { after removal of the non-diet } \\
\text { components of the score with } \\
\text { exception of lung and bronchus }\end{array}$ & $\begin{array}{l}\text { Cox proportional hazard model. } \\
\text { Adjusted relative risk }(95 \% \mathrm{Cl}) \text { for } \\
\text { low (Q1) diet quality v. high (Q5) } \\
\text { Initial } \\
\text { All cancers: } 0.85(0.77,0.93) \\
\text { Colon: } 0.74(0.60,0.99) \\
\text { Breast: } 0.76(0.65,0.89) \\
\text { Bronchus/lung: } 0.76(0.57,1 \cdot 02) \\
\text { After removal of } B M I \text { and } P A \\
\text { All cancers: } 0.92(0.83,1 \cdot 02) \\
\text { Colon: } 1.01(0 \cdot 78,1.31) \\
\text { Breast: } 0.86(0.73,1.00) \\
\text { Bronchus/lung: } 0.73(0.54,0.97)\end{array}$ & $\begin{array}{l}\text { Difficulty measuring } \\
\text { some dietary } \\
\text { guidelines may } \\
\text { reduce quality of } \\
\text { compliance score } \\
\text { Equal weighting of DGI } \\
\text { components may not } \\
\text { best represent data } \\
\text { collected } \\
\text { Limited external validity } \\
\text { due to cohort } \\
\text { participants }\end{array}$ \\
\hline $\begin{array}{l}\text { Osler et al. } \\
\qquad(2001)^{(8)}\end{array}$ & $\mathrm{HFI}$ & 26-item FFQ & $\begin{array}{l}7316 \text { adults aged } \\
30-70 \text { years. } \\
\text { Denmark }\end{array}$ & $\begin{array}{l}\text { Mortality: CVD } \\
\text { including } \\
\text { evaluation of } \\
\text { endpoints for } \\
\text { stroke and IHD } \\
\text { disease deaths }\end{array}$ & $\begin{array}{l}\text { After 15-year follow-up HFI inversely } \\
\text { associated with all-cause mortality } \\
\text { in men and women. This was } \\
\text { attenuated after adjustment for } \\
\text { smoking, BMI, PA, alcohol intake } \\
\text { and education level. HFI not related } \\
\text { to cause-specific mortality }\end{array}$ & $\begin{array}{l}\text { Cox proportional hazard model. } \\
\text { Hazard rate ratio }(95 \% \mathrm{Cl} \text { ) for all- } \\
\text { cause mortality for low (Q1) diet } \\
\text { quality } v \text {. high }(\mathrm{Q} 4) \\
\text { Men } \\
\text { Crude: } 0 \cdot 60(0.43,0 \cdot 83) \\
\text { Adj: } 0 \cdot 82(0.58,1 \cdot 14) \\
\text { Women } \\
\text { Crude: } 0.58(0.39,0.87) \\
\text { Adj: } 0 \cdot 82(0.54,1 \cdot 25)\end{array}$ & $\begin{array}{l}\text { Possible dietary } \\
\text { measurement bias of } \\
\text { short FFQ }\end{array}$ \\
\hline $\begin{array}{l}\text { Fung et al. } \\
\qquad(2006)^{(21)}\end{array}$ & $\begin{array}{l}\text { HEI } \\
\text { AHEI } \\
\text { DQI-R } \\
\text { RFS } \\
\text { aMED }\end{array}$ & $\begin{array}{l}61 \text { items } \\
\text { expanded } \\
\text { to } 116 \\
\text { items on } \\
\text { FFQ }\end{array}$ & $\begin{array}{l}71058 \text { women. Nurses' } \\
\text { Health Study. USA }\end{array}$ & $\begin{array}{l}\text { Incidence of } \\
\text { breast cancer }\end{array}$ & $\begin{array}{l}\text { After 18-year follow-up AHEI, RFS } \\
\text { and aMED associated with lower } \\
\text { risk of ER } \text { R }^{-} \text {breast cancer. RFS had } \\
\text { the strongest association. For each } \\
10 \% \text { increase in scores: AHEI had } \\
11 \% \text { reduction of risk, RFS } 12 \% \\
\text { reduction and aMed } 7 \% \text { reduction. } \\
\text { DQI-R and HEl limited prediction of } \\
\text { breast cancer risk. No association } \\
\text { for total and ER }{ }^{+} \text {breast cancer risk }\end{array}$ & $\begin{array}{l}\text { Cox proportional hazard model. } \\
\text { Relative risk }(95 \% \mathrm{Cl}) \text { for } \mathrm{ER}^{-} \\
\text {postmenopausal breast cancer for } \\
\text { low (Q1) diet quality } v \text {. higher }(\mathrm{Q} 5) \\
\text { AHEI } \\
\text { Age adj: } 0.92(0.71,1.19) \\
\text { All adj: } 0.78(0.59,1.04) \\
\text { RFS } \\
\text { Age adj: } 0.82(0.63,1.07) \\
\text { All adj: } 0.69(0.51,0.94) \\
\text { aMed } \\
\text { Age adj: } 0.89(0.70,1 \cdot 14) \\
\text { All adj: } 0.79(0.60,1.03)\end{array}$ & $\begin{array}{l}\text { Potential influence of } \\
\text { dietary factors on } \\
\mathrm{ER}^{+} \text {tumours may be } \\
\text { difficult to detect due } \\
\text { to strong influence of } \\
\text { hormonal factors } \\
\text { ER }^{-} \text {breast cancer was } \\
\text { only a small portion of } \\
\text { cancers diagnosed }\end{array}$ \\
\hline $\begin{array}{l}\text { Huijbregts et al. } \\
\qquad(1997)^{(7)}\end{array}$ & HDI & Diet history & $\begin{array}{l}3045 \text { men aged } 50-70 \\
\text { years. Italy, Finland } \\
\text { and The Netherlands }\end{array}$ & All-cause mortality & $\begin{array}{l}\text { After } 20 \text {-year follow-up HDI inversely } \\
\text { associated with all-cause and } \\
\text { cardiovascular mortality. Multivariate- } \\
\text { adjusted risk of all-cause mortality } \\
\text { reduced by } 13 \% \text { in highest HDI } \\
\text { group relative to lowest. CVD } \\
\text { mortality risk reduced by } 18 \% \text { in } \\
\text { highest } v \text {. lowest HDI group }\end{array}$ & $\begin{array}{l}\text { Cox proportional hazard model. } \\
\text { Relative risk }(95 \% \mathrm{Cl}) \text { of all-cause } \\
\text { mortality for low diet quality } \mathrm{v} \text {. } \\
\text { Medium diet quality } \\
\text { Crude: } 1 \cdot 00(0 \cdot 88,1 \cdot 30) \\
\text { Age adj: } 0.95(0 \cdot 84,1 \cdot 07) \\
\text { Age, smoking, alcohol adj: } 0.99 \\
(0.87,1 \cdot 11)\end{array}$ & $\begin{array}{l}\text { In analysis it was } \\
\text { assumed that the diet } \\
\text { of } 1970 \text { was indicative } \\
\text { of diet up to } 1990 \text { and } \\
\text { may have attenuated } \\
\text { associations } \\
\text { Some HDI criteria } \\
\text { overlap and some }\end{array}$ \\
\hline
\end{tabular}


four of five cohorts that a higher HDI was associated with lower cognitive impairment. However, this was statistically significant in only one cohort ${ }^{(29)}$. Two studies found the HDI to be inversely associated with all-cause mortality ${ }^{(7,20)}$. One found a $13 \%$ reduction in all-cause mortality as well as an $18 \%$ risk reduction in CVD mortality, with no reduction in cancer mortality risk ${ }^{(7)}$. The other found that the HDI had a significant inverse relationship with all-cause mortality after a 10-year follow-up ${ }^{(20)}$.

\section{Healthy Food Index}

The HFI was used in two assessments of the same population, but reported associations with different outcomes $^{(8,30)}$. The first measured CVD mortality ${ }^{(8)}$ while the second measured risk of $\mathrm{CHD}^{(30)}$. HFI was inversely associated with all-cause mortality in men and women; however, this was attenuated after adjustment for smoking, BMI, physical activity, alcohol intake and education level ${ }^{(8)}$. It was not related to cause-specific mortality ${ }^{(8)}$. The second report found an insignificant, inverse relationship with CHD risk ${ }^{(30)}$.

The Healthy Food and Nutrient Index (HFNI) was used in one study ${ }^{(31)}$. It had a significant association with mortality in men after adjustment for all-cause mortality risk factors. This index showed no significant associations in women.

\section{Recommended Food Score}

The original RFS was used in three studies ${ }^{(9,22,32)}$. RFS was inversely associated with all-cause mortality and causespecific mortality in a study of US women ${ }^{(9)}$. There was a $30 \%$ reduced risk of all-cause and cause-specific mortality in the highest quartile, after age and multivariate adjustment ${ }^{(9)}$. One of the studies that measured AHEI also found that the RFS was inversely associated with chronic disease risk in men, with a $23 \%$ lower CVD risk, and that this was a smaller association than with AHEI ${ }^{(22)}$. The RFS was not related to major chronic disease outcomes in women and did not predict cancer in either gender ${ }^{(22)}$. In contrast to the previous study, another in US women found the RFS to be inversely associated with total mortality, cancer mortality, and mortality from colorectal, lung and breast cancer, with the highest RFS quartile having a reduced incidence of lung cancer ${ }^{(32)}$.

Two studies using a slightly varied version of RFS also found associations with mortality and cancer ${ }^{(21,33)}$. It was inversely associated with all-cause and cause-specific mortality, particularly CHD and stroke, with $42 \%$ reduced allcause mortality ${ }^{(33)}$. One study previously mentioned found the RFS to be associated with a lower risk of ER-negative breast cancer (12\% reduction for each 10\% increase in score), and that it had the strongest association among all the indices used (HEI, AHEI, DQI-R and aMED) ${ }^{(21)}$.

A Not Recommended Food Score (NRFS) was used in a previous study ${ }^{(33)}$ using the RFS, which showed no relationships with all-cause mortality, CHD and stroke mortality. 


\section{Diet Quality Index}

The original DQI was used in one study of US adults ${ }^{(10)}$. After adjustment for multiple covariates the DQI was associated only with circulatory disease mortality in women and it was unrelated to cancer mortality. An improved index, the DQI Revised (DQI-R), was limited in predicting risk of breast cancer ${ }^{(21)}$. Another version of the DQI was modified for use in a Mediterranean population with dietary biomarkers as an outcome ${ }^{(14)}$. It was found to be significantly correlated with EPA and DHA only. This association was still apparent after adjusting for tobacco use, and a correlation with $\beta$-carotene became significant after this adjustment.

\section{Diet Quality Score}

Two variations of the DQS have been used. The first measured all-sites cancer incidence over $8 \cdot 3$ years and found a significant inverse relationship, estimating that the incidence of cancer could be reduced by $\sim 35 \%$ if diet quality was improved ${ }^{(11)}$. The second, using CVD biomarkers, found DQS to be negatively associated with total cholesterol, LDL cholesterol, TAG, homocysteine and absolute risk of IHD after adjustment for age, sex, physical activity level and smoking ${ }^{(15)}$. DQS was positively associated with HDL cholesterol concentrations. Another score, the Dietary Quality (DQ), was used to examine associations with survival after age 45 years ${ }^{(34)}$. The latter study in US adults found that DQ was inversely associated with all-cause mortality, with the relative hazards of death for men aged 55-64 years with the worst DQ after 10-year follow-up being 1.9 compared with those with better diets. The relative hazards of death for men aged $45-54$ and 65-74 years were 1.5 and 1.4 , respectively $^{(34)}$.

\section{Dietary Guidelines Index}

The DGI was used in one study to measure all-site cancer and site-specific cancer incidence and mortality ${ }^{(28)}$. Higher DGI was associated with a significantly lower incidence of all-site cancer and site-specific cancers. This association was no longer significant once guidelines such as be physically active each day were excluded and it was analysed against only diet-based dietary guidelines and cancer incidence, with the exception of lung and bronchus.

\section{Mediterranean Diet Score}

Numerous versions of MDS have been constructed, most with slight variations from the original, mainly in the scoring of fish, legumes and vegetables, as detailed in Table $1^{(12)}$. Six studies used the MDS with most measuring all-cause mortality and cancer mortality as outcomes ${ }^{(12,17-20)}$. The first version found that every 1-unit increase in score was significantly associated with a $17 \%$ overall mortality reduction $^{(12)}$. A second version was used in two studies ${ }^{(17,18)}$. The first study on adults in Greece found the MDS to be associated with reduced total mortality (25\% reduction for a 2-point increase in score) and inversely associated with mortality due to CHD and cancer ${ }^{(17)}$. The second study in Swedish women also found an inverse relationship, with a substantial reduction in all-cause mortality (23\%) and cancer mortality (29\%) in women aged 40-49 years at enrolment ${ }^{(18)}$. This association was not found in women who were aged $30-40$ years at enrolment ${ }^{(18)}$. A third version of the MDS was used to measure all-cause mortality as an outcome ${ }^{(19)}$. It too was inversely associated with allcause mortality; a 1-unit increase in score being associated with $21 \%$ reduced mortality. The study also found higher plasma carotene levels in subjects with higher scores and a negative association between plasma carotene and mortality ${ }^{(19)}$. The fourth version of the MDS was used in a study that also used the HDI and Mediterranean Adequacy Index (MAI) ${ }^{(20)}$. All three indices had a significant inverse relationship with all-cause mortality. An Alternative MDS (aMDS) was used in a previous study on breast cancer and was associated with lower risk of ER-negative breast cancer ( $7 \%$ reduction for each $10 \%$ increase in score) ${ }^{(21)}$.

\section{Mediterranean Adequacy Index}

One study used the MAI to measure all-cause mortality, cancer and other causes of mortality ${ }^{(20)}$. Only all-cause mortality had a significant inverse relationship with MAI, with associations found to be stronger in Northern than in Southern Europe ${ }^{(20)}$.

\section{Total and specific food group diversity}

Three case-control studies of colon and colorectal cancer used total and specific food group diversity ${ }^{(25-27)}$. The first study from Italy found total diet diversity reduced the risk of colorectal cancer by $30 \%$ in the highest quartile of diversity $^{(26)}$. Relative risk appeared to increase by 1.4 with diversity of foods in the carbohydrate group ${ }^{(26)}$. The second study found that total diet diversity had no association with colon cancer in US adults ${ }^{(27)}$. However, men had a 50\% increased risk of colon cancer with greater diet diversity in the meat/fish/poultry/egg group and refined grains group $^{(27)}$. Women had a $20 \%$ lower risk if diet diversity was high in the vegetable group ${ }^{(27)}$. The third study, also in Italy, found total diet diversity to be inversely related to colon cancer risk in men ( $35 \%$ reduction) and that diversity within the vegetable group had an inverse relationship with both colon and rectal cancers ${ }^{(25)}$.

\section{Discussion}

The majority of studies reviewed found that diet quality scores were inversely related to health outcomes, with a protective effect of moderate magnitude. In the studies that did find associations, all-cause mortality was reduced by $17-42 \%$, CVD mortality by $18-53 \%$, CVD risk by $14-28 \%$, cancer mortality by $13-30 \%$, and all-cancer risk 
by $7-35 \%$. The predictive capacity of most indices appears to be in a similar range. However, it is difficult to directly compare results due to the variability of population groups, length of study follow-up periods, dietary measurement methods, index scoring methods and approaches to adjustment for confounders ${ }^{(3)}$. Relative risks were consistently attenuated after adjustment for factors such as BMI, physical activity, age, education, socio-economic status and smoking.

Associations between scores and morbidity and/or mortality varied between genders within studies, and were generally stronger and broader in their associations with adverse health outcomes for men. This suggests that this is a real disparity, although differential gender bias in the original dietary assessment method used to assess usual intake is a possibility.

Specific outcomes, such as cancer risk, were not predicted as strongly or consistently as all-cause mortality or CVD risk. Those indices that did predict risk came from tools based on either a US dietary pattern $\left(\mathrm{RFS}^{(32)}\right.$, AHEI $^{(21)}$ and Total Diet Diversity ${ }^{(25,26)}$ ) or Mediterranean dietary patterns $\left(\operatorname{MDS}^{(18)}\right.$ and aMED $\left.{ }^{(21)}\right)$. One possible reason for the lack of association is study duration, with shorter follow-up obviously not able to capture the latency period prior to cancer detection ${ }^{(11,12,19,23,24,31)}$. Two of the studies that did find associations with cancer risk were case-control studies that measured the diet diversity of participants after initial cancer diagnosis through administration of an FFQ covering the previous year ${ }^{(25,26)}$. However, dietary intake in these instances is likely to be confounded by recall bias and it is difficult to ascertain with this study design in which direction the risk assessment is likely to be affected. All indices have limitations due to the methods with which dietary intake was measured. Instruments such as the $24 \mathrm{~h}$ recall and FFQ all have limitations including over- or under-reporting, and in some studies only a brief FFQ was originally used $^{(8,26,30)}$ or sometimes a single $24 \mathrm{~h}$ recall was used as the indicator of usual dietary intake ${ }^{(13)}$. Having an initial measurement of dietary intake at baseline in cohort studies is a more sensitive way to ascertain prospective associations with disease risk. However, this approach requires long periods of follow-up and is also not without bias and limitations. To strengthen comparisons across studies, researchers ideally could base their index of diet quality on one of the tools commonly used or use more than one of the indices in statistical analyses, as some researchers have done ${ }^{(33)}$. The critical appraisal of study quality found that most studies met at least three of five criteria, with about a third meeting at least four. While outcomes were usually reported objectively and statistical methods appeared appropriate, descriptions of the population sampling, inclusion criteria and subgroups were often poor.

Many components of indices such as the HEI are derived from epidemiological associations with reduced risk of CVD and its risk factors, as opposed to cancer. This may explain why indices appear to have a better risk prediction for $\mathrm{CVD}^{(23)}$. Associations may also be less strong between index components and cancer risk. Most indices have been developed to measure diet quality and adherence to national dietary guidelines (HFNI, RFS, DQS and DGI). While they attempt to show association with higher diet quality, it is difficult to predict the likely degree of association with disease risk if the index was not specifically designed for this purpose ${ }^{(3)}$. For example in the HEI, grains are not differentiated between those that are refined or unrefined, which limits the ability to show effects between whole grains and diseases such as diabetes and heart disease ${ }^{(23)}$.

Indices have their own strengths and limitations which may have affected results in the studies. Indices that have a small scoring scale, such as the DQI and HEI, appear to be less sensitive in this evaluation of indices and fail to capture extremes and intrinsic characteristics of food behaviours or eating patterns. Their discrete distributions within index scoring patterns may reduce their power as a predictor ${ }^{(35)}$. Both the DQI and the HEI have been revised (DQI-R and AHEI) to improve disease risk prediction. AHEI was twice as strong as HEI in its overall chronic disease risk prediction, primarily CVD, in men and women in the USA ${ }^{(36)}$. When selecting or developing a dietary quality index, important considerations include: (i) defining the tool's purpose, such as to capture a global indicator of adherence to specific aspects of a healthful diet or to measure associations with aspects of diet that increase disease risk; (ii) identifying a scoring system that weights the subscales appropriately; and (iii) measuring potential confounders to allow appropriate adjustment for confounders. Further, consideration should be given to including a validation of the score using appropriate biomarkers and disease risk factor assessment. For example, a dietary quality index to measure associations with CVD outcomes could include index components that score type and quantity of dietary fat, measure red blood cell membrane fatty acids as the dietary biomarkers, plasma lipids as the disease risk factors and confounders of CVD as previously described.

Other limitations of study design include small cohort size ${ }^{(6,12,14,19)}$, cross-sectional assessments only with no follow-up ${ }^{(6,13-15,29)}$ and using mortality as the sole outcome, given that fatality may be confounded by early diagnosis, treatment and medical care ${ }^{(24)}$. Therefore indices need to be carefully interpreted to ensure limitations are acknowledged.

\section{Conclusions}

Indices of diet quality are used to measure associations with biomarkers and health outcomes. We found that lower diet quality scores are consistently associated with 
higher rates of all-cause mortality and selected diseasespecific rates or mortality. The associations are attenuated when adjusted for common confounding variables but still remain significant, and appear to be stronger in men and for all-cause and CVD mortality. However, the limitations of these indices and the specific context in which they are used need to be considered when interpreting results and comparing studies. Future validation studies need to examine associations between nutritional biomarkers and intermediary disease risk factors. Not only will this improve the validity of the diet quality indices, but it will also increase their potential practical applications in both clinical and public health contexts.

As there are numerous diet quality indices and variations of each method, it is recommended that researchers model indices on existing tools and select more than one when testing associations with health outcomes. This will allow examination of how robust findings are across the indices and facilitate comparison across studies.

Finally, there is enough evidence to recommend that diet quality tools should be adapted for use in clinical dietetic practice and for self-evaluation of dietary intake, particularly those scored in a way that identifies which foods need to be increased to obtain a more healthful score and therefore potentially reduce chronic disease risk.

\section{Acknowledgements}

The present review was undertaken in partial requirement for the degree of Bachelor of Nutrition and Dietetics (A.W.), School of Health Sciences, Faculty of Health, University of Newcastle. This work was completed at the University of Newcastle. There was no funding for this review. There are no conflicts of interests. C.E.C. and A.W. designed the protocol; A.W. searched the literature and drafted the manuscript; C.E.C. and A.W. revised the manuscript.

\section{References}

1. Kant A (1996) Indexes of overall diet quality. J Am Diet Assoc 96, 785-791.

2. Kant A (2004) Dietary patterns and health outcomes. $J$ Am Diet Assoc 104, 615-635.

3. Waijers P, Feskens E \& Ocke M (2007) A critical review of predefined diet quality scores. Br J Nutr 97, 219-231.

4. Joanna Briggs Institute (2003) Observational critical appraisal form 4.2. http://www.joannabriggs.edu.au/protocols/ chronicconst.pdf (accessed December 2008).

5. Joanna Briggs Institute (2003) Data extraction form 5. http://www.joannabriggs.edu.au/pdf/protonipple.pdf (accessed December 2008).

6. Hann C, Rock C, King I \& Drewnowski A (2001) Validation of the Healthy Eating Index with use of plasma biomarkers in a clinical sample of women. Am J Clin Nutr 74, 479-486.

7. Huijbregts P, Feskens E, Rasanen L, Fidanza F, Nissinen A, Menotti A \& Kromhout D (1997) Dietary pattern and 20 year mortality in elderly men in Finland, Italy, and the Netherlands: longitudinal cohort study. BMJ 315, 13-17.
8. Osler M, Heitmann B, Gerdes L, Jorgensen L \& Schroll M (2001) Dietary patterns and mortality in Danish men and women: a prospective observational study. Br J Nutr $\mathbf{8 5}$, 219-225.

9. Kant A, Schatzkin A, Graubard B \& Schairer C (2000) A prospective study of diet quality and mortality in women. JAMA 283, 2109-2115.

10. Seymour J, Calle E, Flagg E, Coates R, Ford E \& Thun M (2003) Diet quality index as a predictor of short-term mortality in the American Cancer Society cancer prevention study II nutrition cohort. Am J Epidemiol 157, 980-988.

11. Fitzgerald A, Dewar R \& Veugelers P (2002) Diet quality and cancer incidence in Nova Scotia, Canada. Nutr Cancer 43, 127-132.

12. Trichopoulou A, Kouris-Blazos A, Wahlqvist M, Gnardellis C, Lagiou P, Polychronopoulos E, Vassilakou T, Lipworth L \& Trichopoulos D (1995) Diet and survival in elderly people. BMJ 311, 1457-1460.

13. Weinstein S, Vogt $\mathrm{T} \&$ Gerrior S (2004) Healthy Eating Index Scores are associated with blood nutrient concentrations in the Third National Health and Nutrition Examination Survey. J Am Diet Assoc 104, 576-584.

14. Gerber M, Scali J, Michaud A, Durand M, Astre C, Dallongeville J \& Romon M (2000) Profiles of a healthful diet and its relationship to biomarkers in a population sample from Mediterranean southern France. J Am Diet Assoc 100, 1164-1171.

15. Toft U, Kristoffersen L, Lau C, Borch-Johnsen K \& Jorgensen T (2007) The Dietary Quality Score: validation and association with cardiovascular risk factors: the Inter99 study. Eur J Clin Nutr 61, 270-278.

16. Kim S, Haines P, Seiga-Riz A \& Popkin B (2003) The Diet Quality Index-International (DQI-I) provides an effective tool for cross-national comparison of diet quality as illustrated by China and the United States. J Nutr 133, 3476-3484.

17. Trichopoulou A, Costacou T, Bamia C \& Trichopoulos D (2003) Adherence to a Mediterranean diet and survival in a Greek population. N Engl J Med 348, 2599-2608.

18. Lagiou P, Trichopoulos D, Sandin S, Lagiou A, Mucci L, Wolk A, Weiderpass E \& Adami H (2006) Mediterranean dietary pattern and mortality among young women: a cohort study in Sweden. Br J Nutr 96, 384-392.

19. Osler M \& Schroll M (1997) Diet and mortality in a cohort of elderly people in a North European community. Int $J$ Epidemiol 26, 155-159.

20. Knoops K, Groot de L, Fidanza F, Alberti-Fidanza A, Kromhout D \& van Staveren WA (2006) Comparison of three different dietary scores in relation to 10-year mortality in elderly European subjects: the HALE project. Eur J Clin Nutr 60, 746-755.

21. Fung T, Hu F, McCullough M, Newby P, Willett W \& Holmes M (2006) Diet quality is associated with the risk of estrogen receptor-negative breast cancer in postmenopausal women. J Nutr 136, 466-472.

22. McCullough M, Feskanich D, Stampfer M, Giovannucci E, Rimm E, Hu F, Spiegelman D, Hunter D, Colditz G \& Willett W (2002) Diet quality and major chronic disease risk in men and women: moving toward improved dietary guidance. Am J Clin Nutr 76, 1261-1271.

23. McCullough M, Feskanich D, Rimm E, Giovannucci E, Ascherio A, Variyan J, Spiegelman D, Stampfer M \& Willett W (2000) Adherence to the Dietary Guidelines for Americans and risk of major chronic disease in men. $\mathrm{Am}$ J Clin Nutr 72, 1223-1231.

24. McCullough M, Feskanich D, Stampfer M, Rosner B, Hu F, Hunter D, Variyan J, Colditz G \& Willett W (2000) Adherence to the Dietary Guidelines for Americans and risk of major chronic disease in women. Am J Clin Nutr 72, 1214-1222. 
25. Fernandez E, Negri E, La Vecchia C \& Franceschi S (2000) Diet diversity and colorectal cancer. Prev Med 31, $11-14$.

26. Fernandez E, D'Avanzo B, Negri E, Franceschi S \& La Vecchia C (1996) Diet diversity and the risk of colorectal cancer in Northern Italy. Cancer Epidemiol Biomarkers Prev 5, 433-436.

27. Slattery M, Berry T, Potter J \& Caan B (1997) Diet diversity, diet composition, and risk of colon cancer (United States). Cancer Causes Control 8, 872-882.

28. Harnack L, Nicodemus K, Jacobs D \& Folsom A (2002) An evaluation of the Dietary Guidelines for Americans in relation to cancer occurrence. Am J Clin Nutr 76, 889-896.

29. Huijbregts P, Feskens E, Rasanen L, Fidanza F, AlbertiFidanza A, Nissinen A \& Giampaoli S (1998) Dietary patterns and cognitive function in elderly men in Finland, Italy and the Netherlands. Eur J Clin Nutr 52, 826-831.

30. Osler M, Andreasen A, Heitmann B, Hiodrup S, Gerdes U, Jorgensen L \& Schroll M (2002) Food intake patterns and risk of coronary heart disease: a prospective cohort study examining the use of traditional scoring techniques. Eur J Clin Nutr 56, 568-574.

31. Bazelmans C, De Henauw S, Matthys C, Dramaix M, Kornitzer M, De Backer G \& Leveque A (2006) Healthy
Food and Nutrient Index and all cause mortality. Eur J Epidemiol 21, 145-152.

32. Mai V, Kant A, Flood A, Lacey JJ, Schairer C \& Schatzkin A (2005) Diet quality and subsequent cancer incidence and mortality in a prospective cohort of women. Int J Epidemiol 34, 54-60.

33. Michels K \& Wolk A (2002) A prospective study of variety of healthy foods and mortality in women. Int J Epidemiol 31, 847-854.

34. Murphy S, Davis M, Neuhaus J \& Lein D (1996) Dietary quality and survival among middle-aged and older adults in the NHANES I Epidemiologic Follow-Up Study. Nutr Res 16, 1641-1650.

35. Panagiotakos D, Pitsavos C \& Stefanadis C (2006) Dietary patterns: a Mediterranean diet score and its relation to clinical and biological markers of cardiovascular disease risk. Nutr Metab Cardiovasc Dis 16, 559-568.

36. McCullough M \& Willett W (2006) Evaluating adherence to recommended diets in adults: the Alternate Healthy Eating Index. Public Health Nutr 9, 152-157.

37. Alberti-Fidanza A, Fidanza F, Chiuchiù MP, Verducci G \& Fruttini D (1999) Dietary studies on two rural Italian population groups of the Seven Countries Study. 3. Trends of food and nutrient intake from 1960 to 1991. Eur J Clin Nutr 53, 854-860. 